\title{
8
}

567

. B5

\section{The Business Side of Farming}

\section{Farm Records}

J. A. BEXELLL 


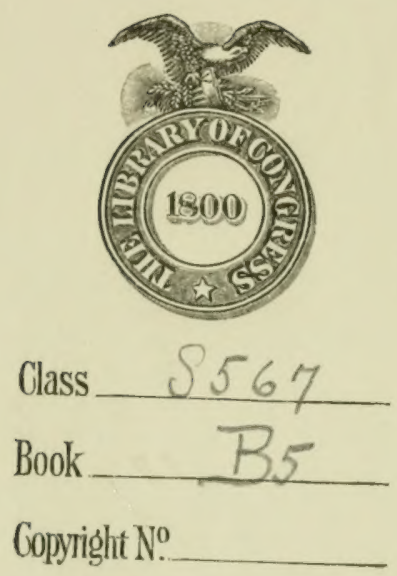

COPYRIGHT DEPOSIT. 


THE

\title{
BUSINESS SIDE OF FARMING
}

\author{
PART I \\ FARM RECORDS
}

A TEXT-BOOK FOR STUDENTS IN AGRICULTURE AND A MANUAL FOR HOME-STUDY

BY

J. A. BEXELL, A. M.

DEAN SCHOOL OF COMMERCE

OREGON AGRICULTURAL COLLEGE 


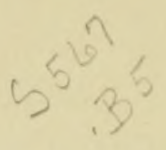

Copyright 1909

By .J. А. BEXnL.

\section{Ruled Blank Books}

with printed headings for use in writing out the exercises, or for practical use on the farm, may be obtained from the College Bookstore, Corvallis, Oregon. Paper, 60c; Cloth, $\$ 1.10$. 


\section{CONTENTS}

\section{PART I}

CHAPTER

PAGE

I. Introductory ................. 7

II. Objects and Methods of Bookkeeping..... 9

III. Single Entry Farm Accounts .........11

IV. Double Entry Farm Accounts........21

V. Household Accounts ............... 30

VI. The Balance Sheet and Statement......35

VII. Cost of Production................ . 40

VIII. Special Records ................ 44

IX. Practice Work in Single Entry ........50

X. Practice Work in Double Entry .......55

XI. Practice Work in Double Entry (Cont'd) . .61

XII. Original Exercises and Review......64 



\section{FOREWORD.}

This manual has been prepared as a text for students in the Business Side of Farming, and is Part I of a work on that subject now in preparation. The complete volume will embrace: Farm Records, Rural Law, and Rural Economics.

There are a number of works on Farm Management now on the market, but I have found none adapted to the class room. This is especially true of works on Farm Records. An arithmetic would be useless as a text without problems for solution; a text on Farm Records is likewise useless in the class room without exercises for practice.

The aim has been to make the exercises as practical and simple as possible, but no attempt has been made to limit the illustrations to actual experience on any particular farm. Hence, both prices and results will probably vary considerably from actual practice, a fact which will not reduce their illustrative value. The forms suggested contain many new and labor-saving teatures, conforming with the best modern business practice. A resourceful teacher will be able to supplement the exercises to any extent to suit the time available and the needs of his class.

The increasing interest shown in this subject warrants the belief that it will be introduced into the public schools in the near future, and surely there is no subject more worthy of attention or more sadly neglected. Suggestions and criticisms from farmers and teachers interested in the subject will receive careful consideration in a future edition.

A complete outfit of the blanks suggested can be obtained from the publisher for $\$ 1.10$ postpaid. 



\section{PART I. FARM RECORDS.}

\section{CHAP'TER I.}

\section{INTRODUCTORY.}

It is a truism to say that the financial side of farming is of the utmost importance. But the fact remains that this side of the world's greatest industry is almost entirely neglected by both the farmer and the schools. Professor Bailey says on this subject: "In visiting practically every farm in one of the counties of the state (N.Y.) we did not find one man who knew how much it cost him to produce milk or to raise any of his crops."

\section{P'rosperity of the Farmer.}

The Secretary of Agriculture, in recent Year Books, points out the remarkable prosperity of the farmer; that the export of farm products is vastly in excess of all other exports combined; that a million agricultural debtors have been transformed during the last ten years into the same number of surplus depositors; that "contrary to his reputation, the farmer is a great organizer, and he has achieved remarkable and enormous successes in many lines of economic co-operation in which the people of other occupations have either made no beginning at all or have nearly if not completely failed.' He points out that most farmers live better than the average merchant or mechanic.

Causes of Success.

It is doubtless true that the farmer is becoming a factor to be reckoned with in the business world; that the average farmer knows vastly more about scientific farming than his father did; he understands more thoroughly the value of proper cultivation, of fertilization, of rotation of crops, and of diversified farming; but it cannot be said that he owes his success to improved business methods. He has been successful, rather in spite of his ignorance in this respect, and because of the lavish generosity of mother nature. 


\section{Two Pluases of Farming.}

The business of farming assumes two distinct phases: the moductive phase and the exchange phase. The one aims to extract the treasures from the soil; the other, to place them in the hands of the consumer. It is important not only to raise abundant crops, but also to sell the products to advantage.

\section{Importance of the lixchange l'hase"}

The importance of the exchange phase is often lost sight of. A farm may be forced to yield to its maximum capacity, labor may be managed properly and waste reduced to a minimum; and ret the net result may be a loss at the end of the year. As a general economic proposition, it might be said that large crops often result in scrious loss to society as a whole. If the net value to the consumer is less than the labor and capital espended on the (rop, society is the loser by the difference. Hence the importance of a thorough understanding by the farmer as well as by the merchant and manufacturer of the laws and methods of exchange or commerce.

\section{Farming a Paying lousiness.}

That farming is a science has been emphasized so much that the fact that it is also a business is often lost sight of. It is a real business, and one which pays the United States close to eight billion dollars annually. It has been demonstrated repeatedly that no legitimate business pays better than farming. It may be a li tle more up-hill work at the start, since most f:rmers begin business with small capital, but it is incomparahly safer in the long run, and will insure a competence for old age with greater certainty than any other occupation. But let it ever be borne in mind that the condition for success is that furming must be conducted on business principles. 
CIIAPIER II.

\section{OBJECTS AND METHODS OF BOOKKEEPING.}

Accurate records and accounts are absolutely necessary in the management of every business enterprise, great or small. No business can be successful in the long run unless its condition can be determined at any time, and no conservative business man will fail to prepare a financial statement at the end of his fiscal year. He must determine how he stands, not only with others, but with himself.

\section{Objects of Keeping Accounts.}

One object of keeping accounts is to assist in accumulating property. Another important object is to record a continuous history of business transactions for future guidance. Not only is this profitable, but it is a source of real pleasure and satisfaction to know our standing with those with whom we deal as well as the profits and losses in our business entelprises.

\section{What the Records Should Show.}

A complete system of farm records should enable the farmer to tell at any time how his business stands with himself and others; the cost of production of staple crops and live stock, and the periodical results of both the productive and the exchange phase of his operations. The records should also show personal and household expenses, and finally a comprehensive history of the various phases of the enterprise, including plats of crop rotation, fertilizing, etc.

\section{Difliculties of Farm Bookkeeping.}

Numerous systems of farm bookkeeping have been proposed, but the trouble with them all is that they are either too complicated or altogether unpractical. Professor Bailey says: "The entire subject of farm accounting must be attacked in a new way. The ordinary bookkeeping will not apply." The reason is obvious. Farming is a much more complicated business than most people suppose. A farmer is both a producer and a dealer. He needs financial records as complete as the average merchant and cost records as accurate as the manufacturer. But the records must be adapted to the business in hand. "The ordinary bookkeeping will not apply." The farmer is usually a very busy man. His chief difficulty is neither ignorance nor indolence. He has little time for fancy book- 
keeping and still less for "red tape." What he wants is a plain, simple, straightforward history of his business; so arranged and classified as to require the minimum effort to keep it up. It may be interesting for his children to learn the conrentional use of red ink, rulings, closing of books, the intricacies of journalizing, etc., but all this is not necessary to a keeping whereby the yearly profit or loss may be determined by a proper understanding of farm bookkeeping.

\section{Mcthods of Bookkeeping.}

In the fo!lnwing pages I suggest two methods of farm bookkeeping whereby the yearly profit or loss may be determined and compared from year to year. The first is extremely simple Single Entry, while the second method is a comprehensive, but vely simple Double Entry, by which the financial standing, the cost of production, profits and losses, etc., can be ascertained at any time. Any farmer with average intelligence will be able to master it with small expenditure of time and labor. 


\section{CHAP'IEIR III.}

\section{SINGLE ENTRY.}

\section{The Day Book.}

The most important record in this method of bookkeeping is the Day Book, or what might properly be called the Histor'y of the Farm. This should be written in the form of a diary, without attempting a close classification of the entries. Always bear in mind, however, that it is safer to give too much rather than too little information in the records. The Day Book should contain any memoranda which might prove valuable for future reference. Conditions of the weather, time of planting, breeding, division of fields, sales, purchases, loans, attendance at conventions, valuable recipes, etc., are proper subjects for entry. Though it is advisable to keep the book as neat as possible, it is unnecessary to spend much time for that purpose. It is more convenient to jot down items in lead pencil as they come along, and then, as time allows, classify them under their respective heads.

\section{The Day Book and Cash Book Combined.}

In the form below, the Day Book and Cash Book are combined. The ruling is that of an ordinary stock Day Book. In the left-hand column is entered all sums received and in the right-hand column all payments.

While the combined Day Book and Cash Book has the advantage of extreme simplicity, it is often more satisfactory to devote a part of the Day Book, or a separate book, exclusively to cash transactions. Where this plan is followed, it is unnecessary to record all the Cash items in the Day Book. The left-hand page is used for cash receipts and the opposite page for payments.

\section{Bill and Receipt File.}

A very important part of the farm records is the Bill and Receipt File. A part of the Day Book can be devoted to that purpose, but it is better to provide a separate book. In it should be securely pasted all bills for machinery, implements, tools, livestock, nursery stock, furniture, etc., which will be subject to inventory, but not bills for supplies, feed, table expenses, etc.; also receipts for the payment of money, cancelled notes, certificates of pedigree, important clippings from periodicals, and any other matter of interest. This will prove an invaluable-record for future guidance. 


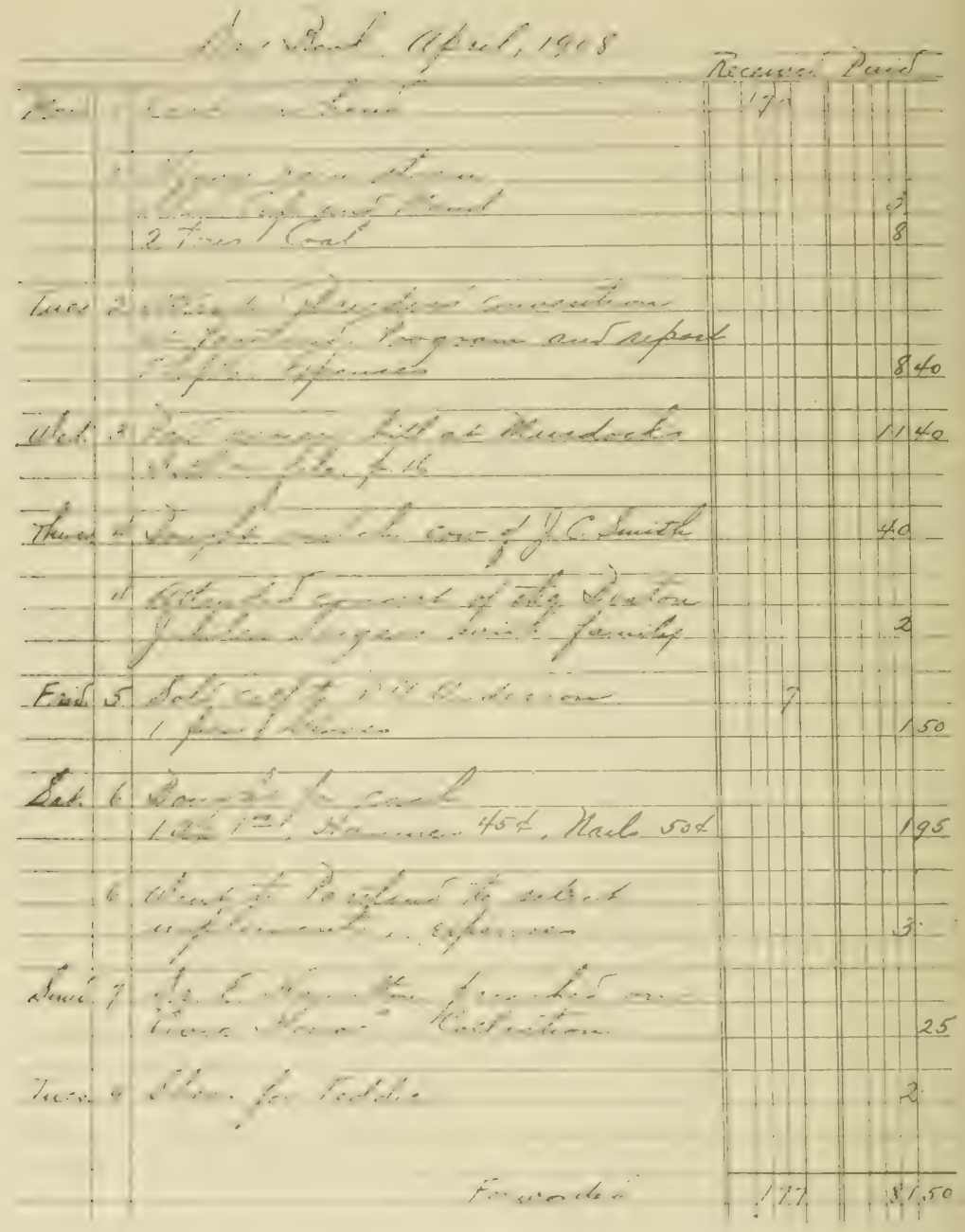

\section{DAY BOOK}




\section{The Inventory.}

The inventory may be considered the most important document among the farm records, because without it no results at all can be ol)tained. It should be taken at such a time as will give the most accurate results with the least expenditure of labor. This differs widely in different localities. January 1st seems the most natural beginning of the fiscal year, but the objection is that at this time there is apt to be a large quantity of feed and supplies on hand.

April 1st would be a better date so far as the stock on hand is concerned, but inconvenient in many localities on account of the pressure of spring work. Whenever it is taken, it should be accurate. No guess work should be tolerated. Weigh and count; do not esimate. Then assign the actual market value to the property, taking due account of depreciation.

\section{Depreciation.}

Neither an old wagon nor an old horse is worth as much as new ones. The same holds true with very few exceptions of all equipment, animals, houses, and improvements. The question as to what rate shall be charged off annually, so as to create a sinking fund with which to renew the depletion, has been an open question with accountants since time immemorial. It is particularly difficult to determine the depreciation of live stock, work horses, and depletion of the fertility of the soil. Without entering into a discussion of the subject, I give below the experience and opinion of the best authorities on the subject. The thoughtful farmer will find no difficulty in adjusting these rates to suit his conditions. For the purpose of general estimates, the following rates on the cost or market value are fairly accurate:

Buildings (including insurance and repairs). 5 per cent.

Horses, above 5 years.............. 10 per cent.

Milch cows ..................8 per cent.

Machinery and tools ..............10 per cent.

Depletion of land on account of continued cropping after fifth crop............ 2 per cent.

\section{How to Determine the Profits.}

The all-important question at the end of each year is: Has the work for the year been a financial success or failure? To determine the profits or losses is, therefore, a problem to be solved each year. As a matter of fact, it is a very simple problem, and it becomes easier the oftener it is done.

Let us assume that heretofore you have kept no books whatever, but you have now decided to make a start. You have pro(ured a simple, substantial I)ay Book (may be purchased at any 


\section{Day Boot Aforel 1, 1908}

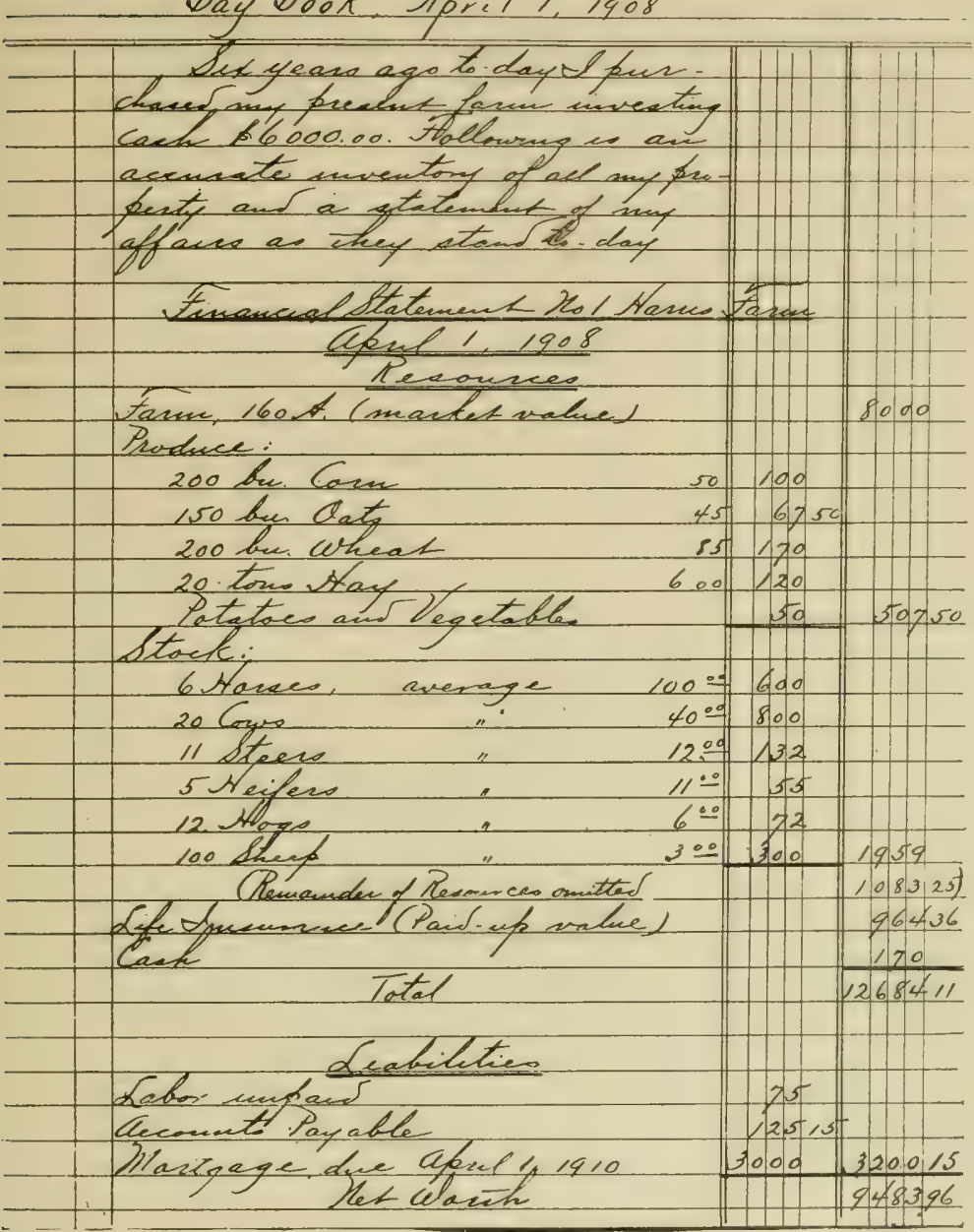

OPENING ENTRY AND INVENTORY 
stationery or (lrug store), and after listing all your property, you are frepared to make the contries shown in the illustration. April 1st is solected as the beginning of the fiscal year, because on that date the supplies, grain, feed, etc., are usually low, and the average farmer has considerable time to spare. Of course, this varies in diflerent localities, and any other date maty be adopted to suit the farmer's convenience. The proper oining entries, including the inventory, are as follows:

\section{Year Later.}

A rear has passed and we are now ready to determine the rasult of the rear's work. Since we have kept the only memoranda in the day book, the best we can do is to take another inventory exactly similar to the last one. This we will now proceed to do.

The second financial statemeni and the statement of Profit and Loss are illustrated on page 17. 


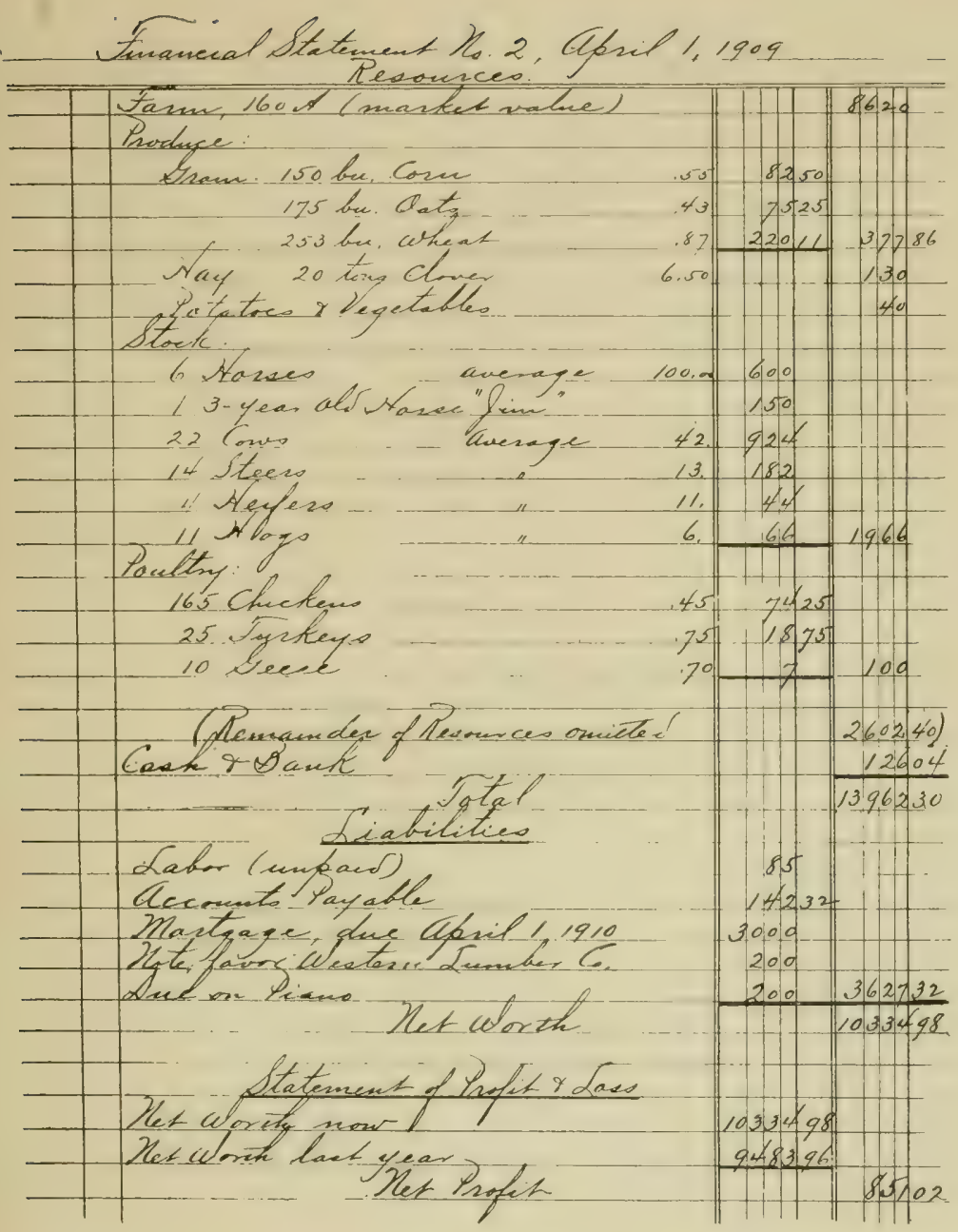

SECOND FINANCIAL STATEMENT 
18

THE BUSINESS SIDE OF FARMING

Others Owe Us

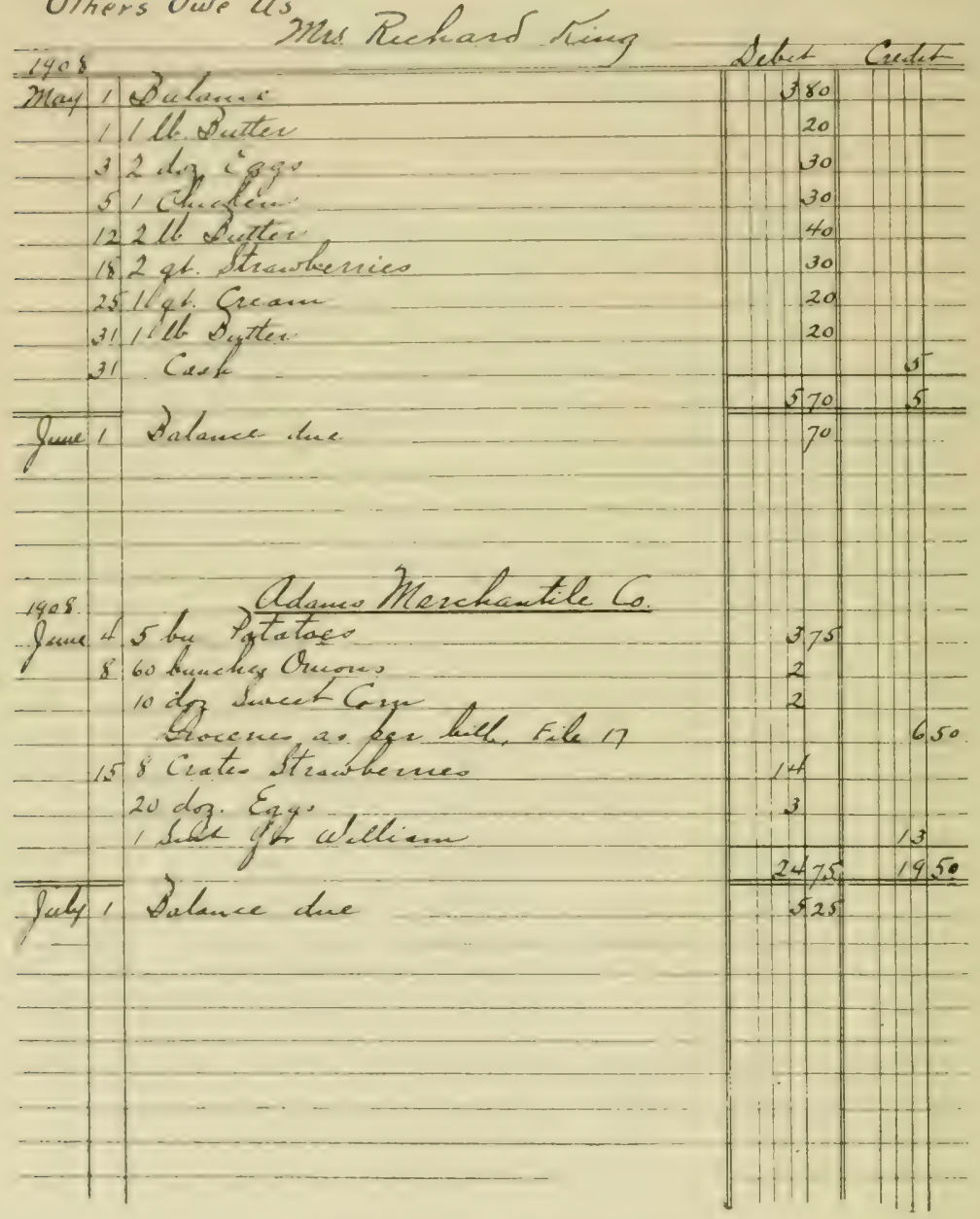

PERSONAL ACCOUNTS 


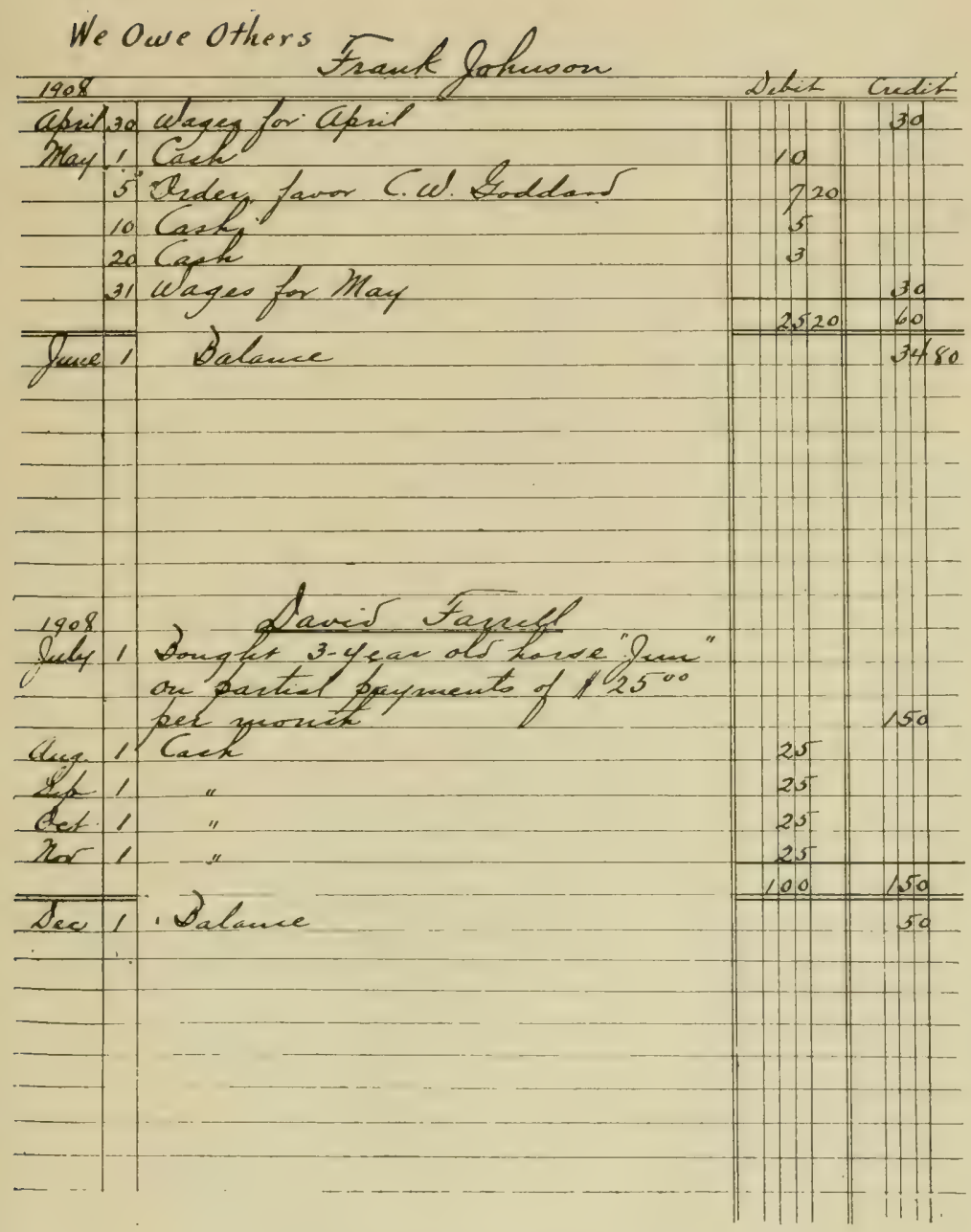

PERSONAL ACCOUNTS 
Continued Inventories.

It is often convenient to tabulate the annual inventories as follows:

\begin{tabular}{|c|c|c|c|}
\hline ITEMS & $\begin{array}{c}\text { April } 1 \\
\text { 19us }\end{array}$ & $\begin{array}{c}\text { April } 1 \\
1909\end{array}$ & . \\
\hline $\begin{array}{l}\text { Varm, } 160 \text { acres (market value) } \\
\text { Produce- } \\
\text { Stock } \\
\text { Poultry } \\
\text { Life Insurance } \\
\text { Cash }\end{array}$ & 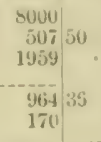 & \begin{tabular}{r|r}
8620 \\
547 & 840 \\
1966 & \\
100 & \\
126 & 04
\end{tabular} & \\
\hline Total & 1268411 & 13962 & \\
\hline
\end{tabular}

\section{l'ersonal Accounts.}

A farmer frequently retails his products to his neighbors or to townspeople, if he lives near towr. In such cases it often happens that he can sell to better advantage by rumning an account with steady customers, collecting by the week or month. If this phase of the business is extensive, as is the case in truck f:urming, dairy, poultry, and the like, it would pay the farmer to frovide tickets or coupons and sell five or ten dollars' worth in advance even at a small discount. But generally an account with each customer, kept either in a separate book or in part of the Day Book, will be found satisfactory. However, most farmers sell their products for cash, or exchange for merchandise, which is equivalent to cash sales. It is, therefore, unnecessary to enter into an elaborate discussion of keeping such accounts.

Some farmers, very unwisely, attend to the personal business of their hired help, even to the extent of buying their - smoking tobacco. There is absolutely no excuse for such a practice. Rather pay your help in installments and let thom settle their own bills.

Accounts with persons we owe are generally unnecessary. Most merchants furnish either a pass book in which the account is shown in detail, or an itemized bill is furnished with each purchase. These bills should be pasted in the Bill File and checked off when paid. In the great majority of cases this will prove more satisfactory than ledger accounts.

A special ledger can be provided, or separate pages of the Day Ibook devoted to special accounts. This classification is mate either daily, weesly or monthly, as time and cireumstances allow. 


\section{CHAPTER IV.}

\section{DOUBLE ENTRY.}

\section{Ancient Methods.}

Not many generations ago it was considered sufficient for the average manufacturer merely to record his cash receipts and expenditures and to keep a tolerable accurate check on the cash balance. In many instances, the left trouser pocket served as the debit side and the right as the credit side of the "Ledger." Miodern business methods and sharp competition nave changed these notions until today it is necessary to know the cost of production in advance to the smallest detail. Ancient business methods prevail yet, very generally, on the farm. The wonderful progress of the American farmer is due to marvelous natural resources, labor-saving inventions, and natural ingenuity, rather than to wise and prudent management.

\section{Necessity of Careful Management.}

In certain respects, a farmer must combine the methods of the manufacturer and the merchant. He must learn not only how to increase production but also how to facilitate the profitable exchange of his products. He must reduce the cost of production to the minimum by increasing the quality and the quantity of his products, and by getting full value out of labor. He must manage so that his working force, farm hands, children, horses, all, are constantly employed. This requires most skillful management in the rotation of crops, in the division of labor, in selecting szeds, fertilizers and stock; and, above all, it requires general prudence in purchasing equipment and supplies, and in marketing products. This class of farmers require a variety of records to assist in the proper management of their business. A first-class set of books is just as indispensible to them as to the banker or to the manufacturer.

\section{Superiority of Double Entry.}

A careful comparison of the results obtained in the last chapter with the balance sheet given below will convince the reader of the superiority of double entry. It will be observed that the only result obtained by a comparison of inventories was the net profit or loss. The source or causes of these results cannot be obtained by this method. The method suggested in Chapter III has this advantage: There is not a farmer so busy or so ignorant that he cannot adopt it and 


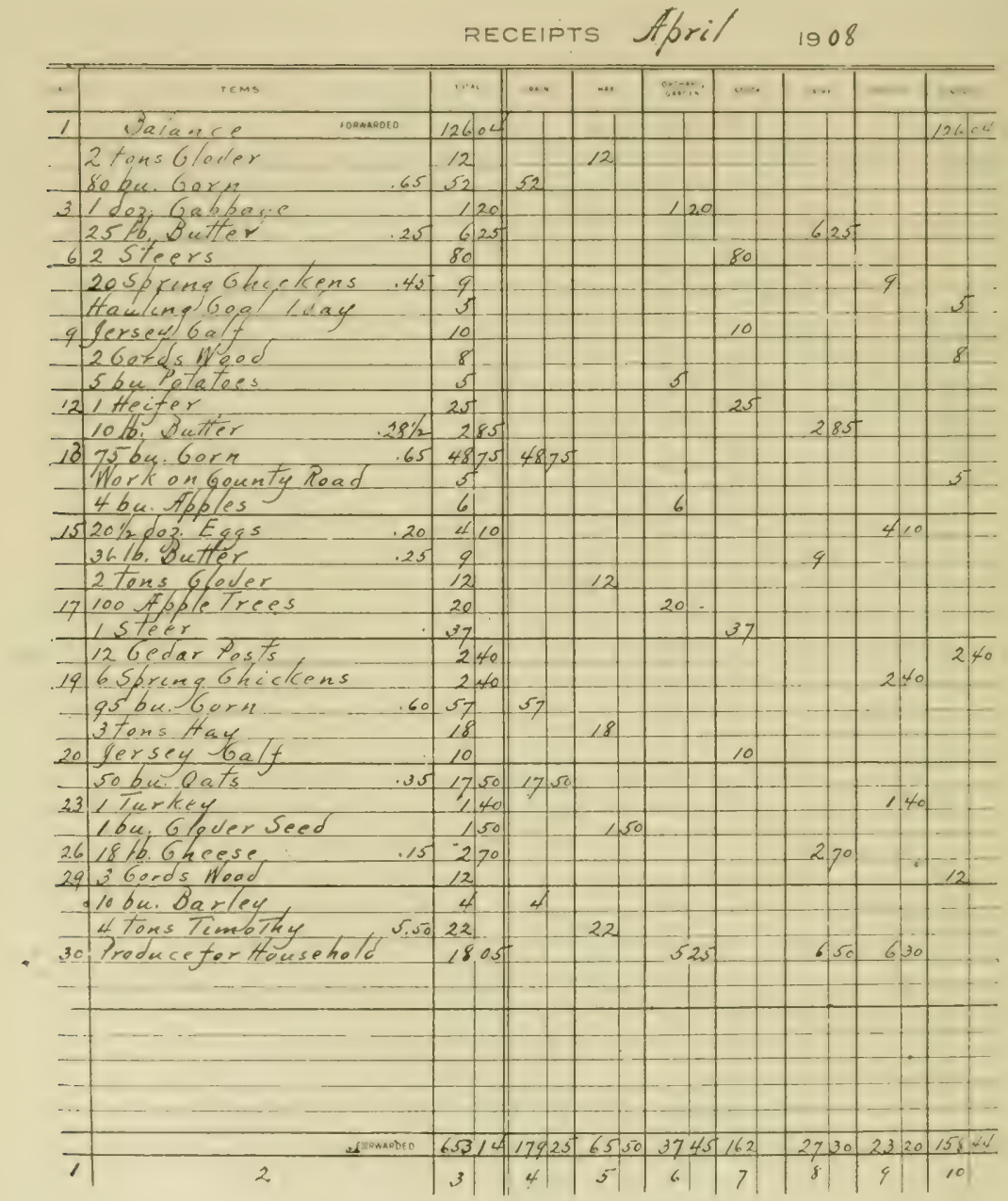

GENERAL FARM 
PAYMENTS

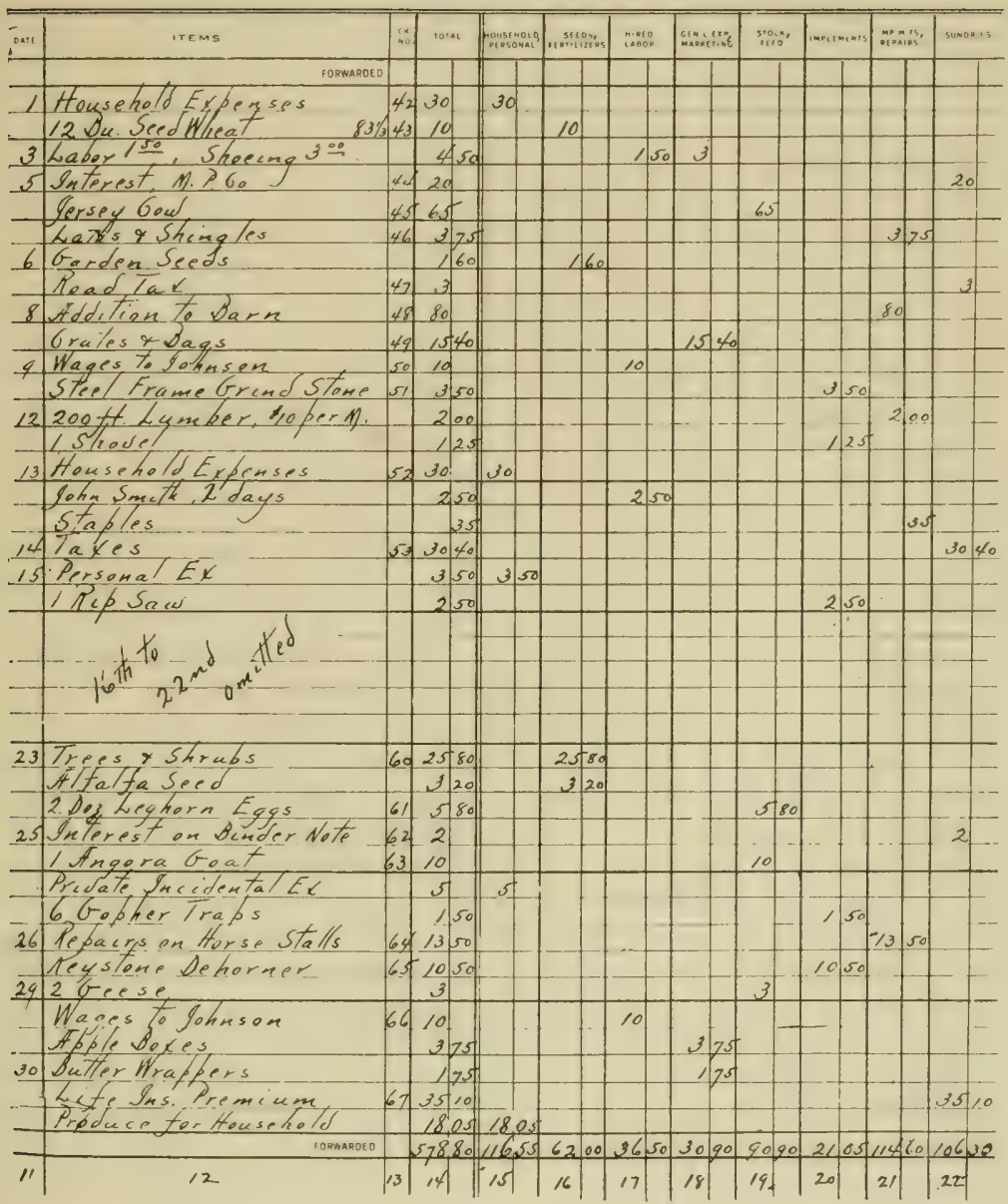


chive reat benefit from its use. But the ambitious, progresslve farmer will not he satisfied whth this primitive method any more than a wide-awalie imerchant will be satisfied with single entry lookliesping. He will arlopt a system which will give lam at any time relialole information as to his financial slanding, (ast of borluction of cops, live stock and poultry, houschold cxponsos, etc., and hy which he can prove that his work is correct.

\section{Single and bouble lintry Compared.}

The distinction between single and double en ry is unimportant for our present purpose, but it may be a satisfaction to the student to know that the me:hod we are now to consider is doulle entry. The important distinction between the two misthols is that in double encry, accounts are kept with perscos, property, and allowances, while in single entry, accounts are kept with persoms only. In double entry there is a correspondirg clebit for every cuedit; the total debits and credits must herefore be ealual, and must balance at any time. This hrcomes clear by referring to the Cash Book below. In the first entry, the amount is entared in loth the Total and in the Sindries columm; and the same is true of all the succeeding chtries. Hence the sum of columns four to ten inclusive must coual the total in column three. You will find the same to be true of the Parments, and of the Household Accounts.

\section{Additional Books Needed.}

Tery important books in double as well as in single entry are the Day Book and the Bill File. They are to be kept in exactly the same way as suggested under single entry, except that no cash entries are recorded in the Day Book. The important comsideration now is to adopt additional records that will furnish the necessary information in systematic and tabulal form, and reapuiring the minimum amount of labor.

\section{The Cash Book.}

The Cosh linoli is the basis of classification. A very convonient folm is riven helow. The special columns take the place of a ledger. All money columns except the total column will he referred to as Distribution Columns. They are in rality sepalate accounts, and this form might, therefore, moperly be called a combined Iedger and Cash Book. The form suggested lias the important adrantage of being selfbalancing. A trial balance can be taken at the end of each lage, month or year, as illustrated on page 34. The process (i) ploparing a financial statement hecomes extremely simple ly this mothod. A few observations regarding equipment and supplies, improvement and repairs will be of assistance in using the distribution columns. 
Equipment and Supplies.

In accurate accounting, the question often arises: What shall be considered equipment, and what supplies? Supplies are defined as expendible or consumable materials, which are incapable of being used more than once; while equipment is of more permanent character, articles which can be used repeatedly. Fuel, lubricating oil, cotton waste, feed, etc., are supplies, while machinery, furniture, and apparatus of all kinds are equipment.

\section{Improvement and Repairs.}

The distinction between improvements and relair 3 is not always clearly understood. An improvement alds value to the property, in the shape of equipment, buildings, drains, fences, and the like, while repairs merely keep un the property. A coat of paint on an unpainted building is an improvement; repainting is classed under repairs. This distinction is very important in making an inventory. Impryenents are added to the inventory, repairs are not.

\section{Cash Balance and Sundry Columus.}

The cash balance is found as follow:

'l'otal receipts. . . . . . . . . . . . . . . . . . . \$653.14

Total payments................ 578.80

Balance

$\$ 74.34$

Note tha' the totals of columns four to ten equal the total of column three; and that columns fifteen to twenty-two equal column fourteen. The Sundries column contain all entries which do not fail under the special columns. At the end of the year the items are segregated under various titles. The segregation for the month of April is a follows:

Sundry Receipt Column (10):

Balance ...................... \$126.04

Labor ... . . . . . . . . . . . . . . . . . 10.00

Wood ....................... 22.40

Total . . . . . . . . . . . . . . . . . . . \$158.44

Sundry Payment Column (22) :

Interest ................... .\$22.00

Taxes ...................... 33.40

Accounts Pay..................... 15.80

Insurance ....................... 35.10

Total .......................\$106.30

Improvemèts and Repair Column (21):

improvements ................ 80.00

Repairs .................. 34.60

Total ...................\$114.60 
Trial Balance.

In the language of the accountant, a trial balance is a test of the equality of the debits and credits in a set of double entry books. Our trial balance is much simpler; it is simply a test of equality of the total columns and the distribution columns, In the Cash Book, merely add the distribution columns on each side and note that their sum equals the respective total columns. The Household and Shop accounts are balanced in the same manner.

\section{The I3ank Account.}

The 'Banking Habit' "arries with it many advantages. Important among them are:

1. The depositor's credit and influence is measured largely by the size and regularity of his bank account.

2. A tendency to economize by a desire to increase the bank balance.

3. The banker becomes your bookkeeper and business counselor.

4. Security against fire and robbers.

5. Endorsed checks are both records and receipts of payments.

6. A benefit to the community by keeping the money in circulation.

The practice of banking is as follows: Record the check numbers, as indicated in column thirteen. The checks are sutisfactory receipts, but the itemized bills should be pasted in the Bill File and bear the same number as the checks. The b:ink will usually furnish all necessary stationery free of (ilarge. The bank balance is considered a part of the cash on hand so that 1.o special account except the check stubs and passbook, need be kept with the bank. The bank balance is proved each month as follows: Arrang? the checks returned numeri(:ally. List the checks not returned; add the outstanding checks to the balance shown in your check register or on your pass-book. It is often convenient to keep a special check register. Following is a convenient form, showing the method of pioving the balance at the bottom of the page.

\section{Whe Ledger.}

W'ith a special column cash book, the ledger can he dispensed with in most cases. The further classification of the sundry columns can be done at the end of the year, as illus1.ated on page 25, and a for pages of the Day Book can be dewed to "What We Owe Others". and "What Others Owe Us." Where a special ledger is found necessary, the form shown below can be used. 
Marten Harres in account with Getezens'Nat Picete

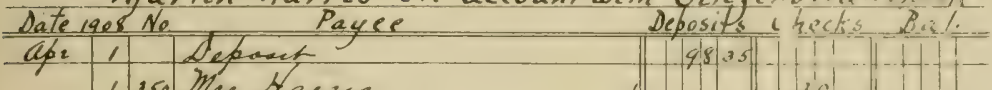

1.350 Mns tran

32 Enema fohmeon.

2 Srown 9 Peched

Asprecer

5 . Salimetinplement C

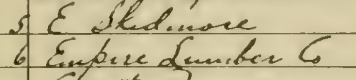

67 Sinity $\lambda_{c}$ conder

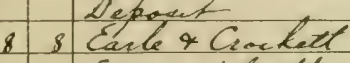

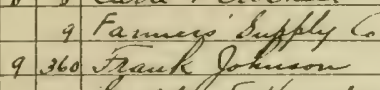

1 boddard tacdware $C_{0}$

2 Her Hawn

Depoest

4 . Cromer Festelizen $C$

13 Neferact.

- Conaty Treamer

6 Sunbael 2 faregey 6

20) s. C Olan r bou

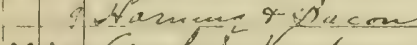

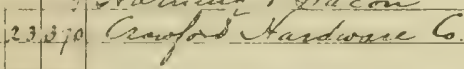

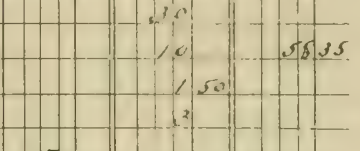

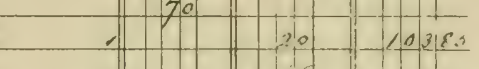

90

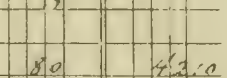

- <.5.4.

$1 \quad-3^{2} 50$

40 so

$-1 \begin{array}{r}6 \\ 4200 \\ 420\end{array}$

125

3o.to

$1 \quad \begin{aligned} & 1 \\ & -250 \\ & 135\end{aligned} 6360$

Proof.

Haxes abone

Litatued ding.

72. 361

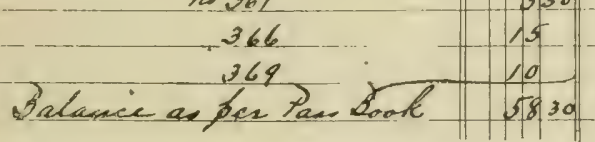

2980 
'The old style ledger possesses some advantages over any other form. The deloit appears on the left and the credit on the right side on the same page. It is used either in double or single eitry. The difficuliy of kecping the ledger in balance prevents the use of the double entry ledger to a very large extent. This i.s especially true if an attempt is made to use the ordinary Journal.

Direct entries into either the double or single entry ledger present less difficulties, and the method is recommended where the classification of accounts is such as to make the combined Cash Book and Ledger unpractical. This need scarcely ever ho the case, however, because if ruled sheets cannot be obtained without headings, a blank sheet may be ruled with any number of columns and headed with titles to suit. For example, an o.chardis. would head his Eeceipt Columns: Apples, Prunes, Peaches, Small Fruits, etc. While an exclusive stock farmer would derote special columns to the different kinds of stock.

The advantage of the ledger method is that each account is more condensed, while the self-proving and labor-saving features are important in the Special Column Cash Book. Preparing a trial balance and balance sheet, and closing the ledger properly, though very simple for the experienced accountant, reguires a proficiency in bookkeeping few farmers possess.

Below is an illustration of the ordinary form of direct-entry ledger, showing the entries for April 1st. Compare these with the first entries on page 22 , and note the similarity of results. In the form below, follow the arrows and note that there is a (hibit for every credit, and vice versa. In the column marked (a) is entered the Day Book page, if the entries have been previously made in that book. 


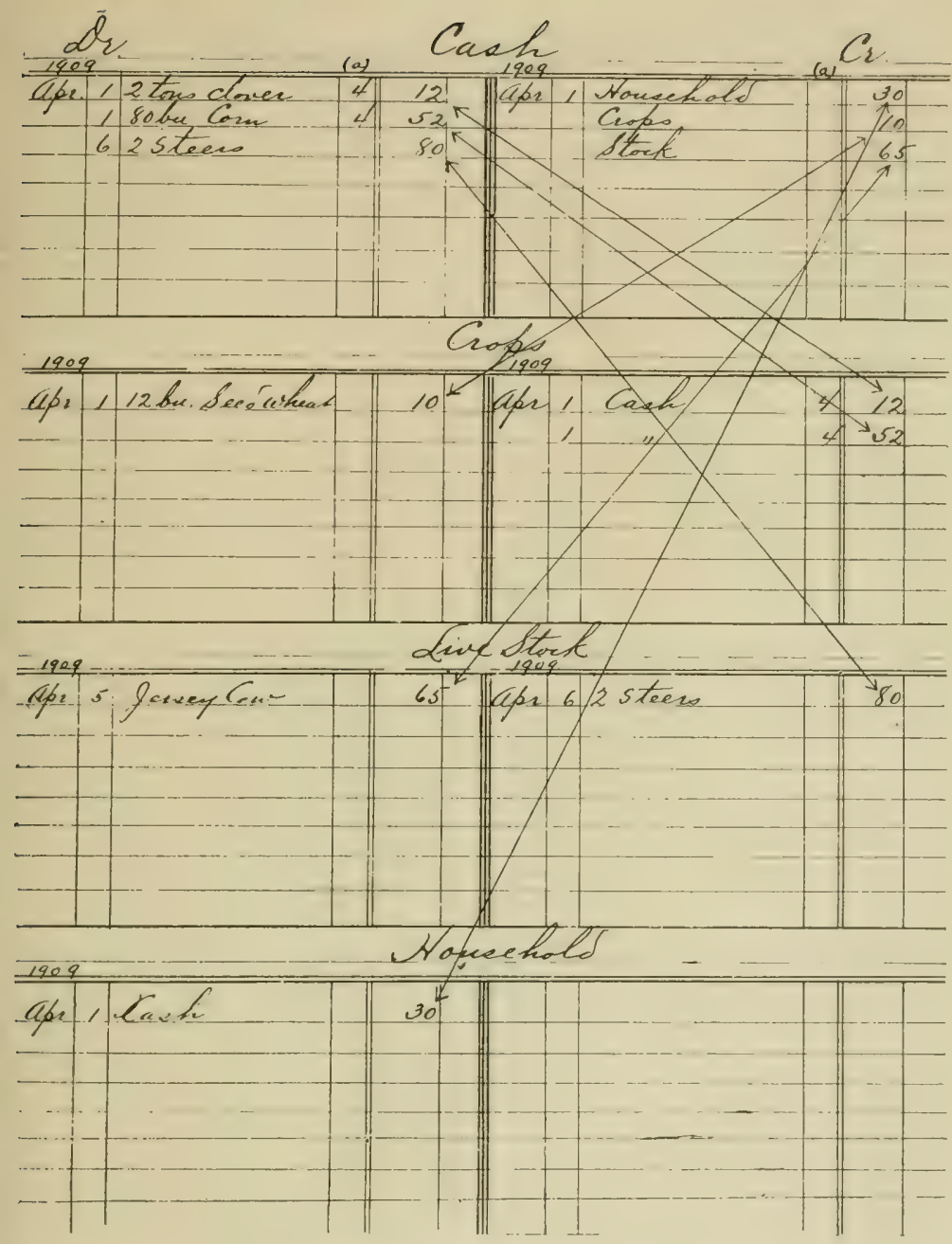

DOUBLE ENTRY LEDGER 


\section{HOUSEHOLD ACCOUNTS.}

It will be seen that no provision has been made in the General Cash Book for separate items in the household accounts. This is left for the houselieeper. 'The fact that her field is somewhat limited from a business point of view is no argument in favor of loose and careless methods of accounting.

Most housekeeper's prefer to receive a fixed allowance for household expenses, whenever it is practicable. For our present purpose we will suppose that the following agreement has been entered into between the farmer and his wife. She is to receive the following:

Monthy Allowances for Houschold and Personal Expenses.

For proprietor and wife. . . . . . . . . . \$25.00

Board for hired help.............. 15.00

For four children. ............... 32.00

Sundries .................... 18.00

$\$ 90.00$

In addition to the cash allowance, regetables, poultry and dairy products are furnished from the farm at market price. The proprietor gives his wife an allowance of $\$ 90$ each month either in one or in several payments, and enter's it in his cash expenditures. His wife, in turn, enters her allowance in her record. Bills for furniture, clothing, and utensils are pasted in a Bill and Receipt File, same as in the Farm Accounts.

Note that the items entered in columns one or two are also entered in collimns eight, nine, or ten, since they are purchases from the farm. Because they are entered both as receipts and payments, they do not affect the cash balance.

At the end of the year, the proprietor enters the totals of columms one and two in his cash receipts under the proper headings, and at the same time they are entered as cash payments in the household column. See page 22. inder April 30th. Thus, the farm will receive full credit for what it sells to the household as well as to others.

It is suggested that the housekeeper open a private bank account and pay large items by check. See April 13th, 29th and 30 th. There are numerous advantages in keeping a bank account. See page 26. A hill for furniture, utensils, and immoroments should always be taken and pasted in the Bill File. It is convenient to number the bills the same as the checks, as 
uggested in column six. Since endorsement by the payee onstitutes receipt, it is generally unnecessary to take receipt when payment is made by check.

Page 30 shows a convenient form of a combined household Jash Book and Ledger. A summary of the receipts and paynents is prepared at the end of the year, as shown on page 33.

Trial IBalance.

Aroceries

$\$ 13.05$

Meat.

airy and Poultry

lothing

urniture and Utensils

22.05

I1.60

Ielp and Laundry

ilorary

6.10

ight and Fuel

2.35

iifts

1.25

'ersonal

3.00

Travel and 1

2.65

hysician and Medicine.

1.50

1.50

celephone Rental....

1.50

Total

$\$ 112.75$ 
HOUSEHOLD ACCOUNTS

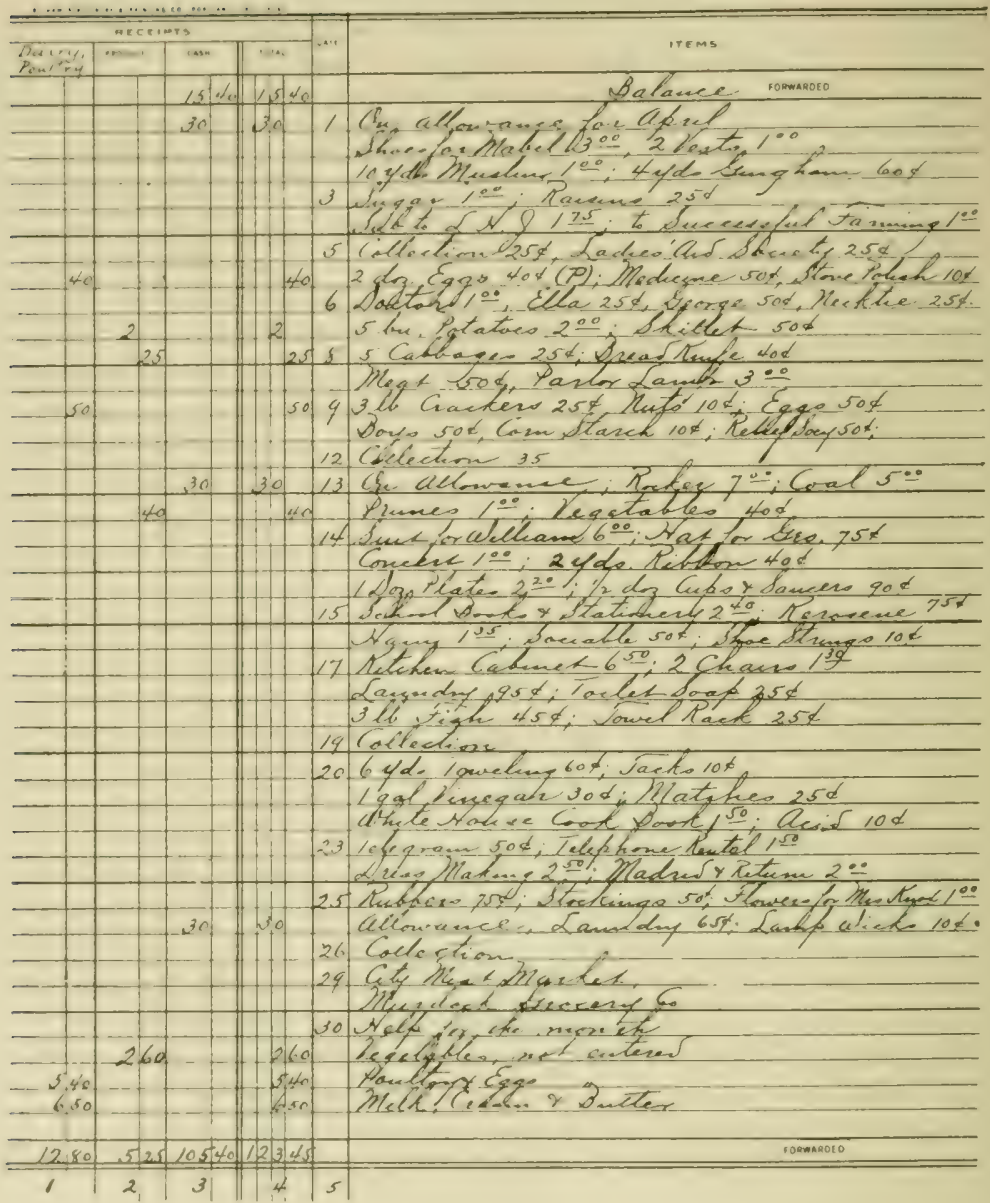

HOUSEHOLD 


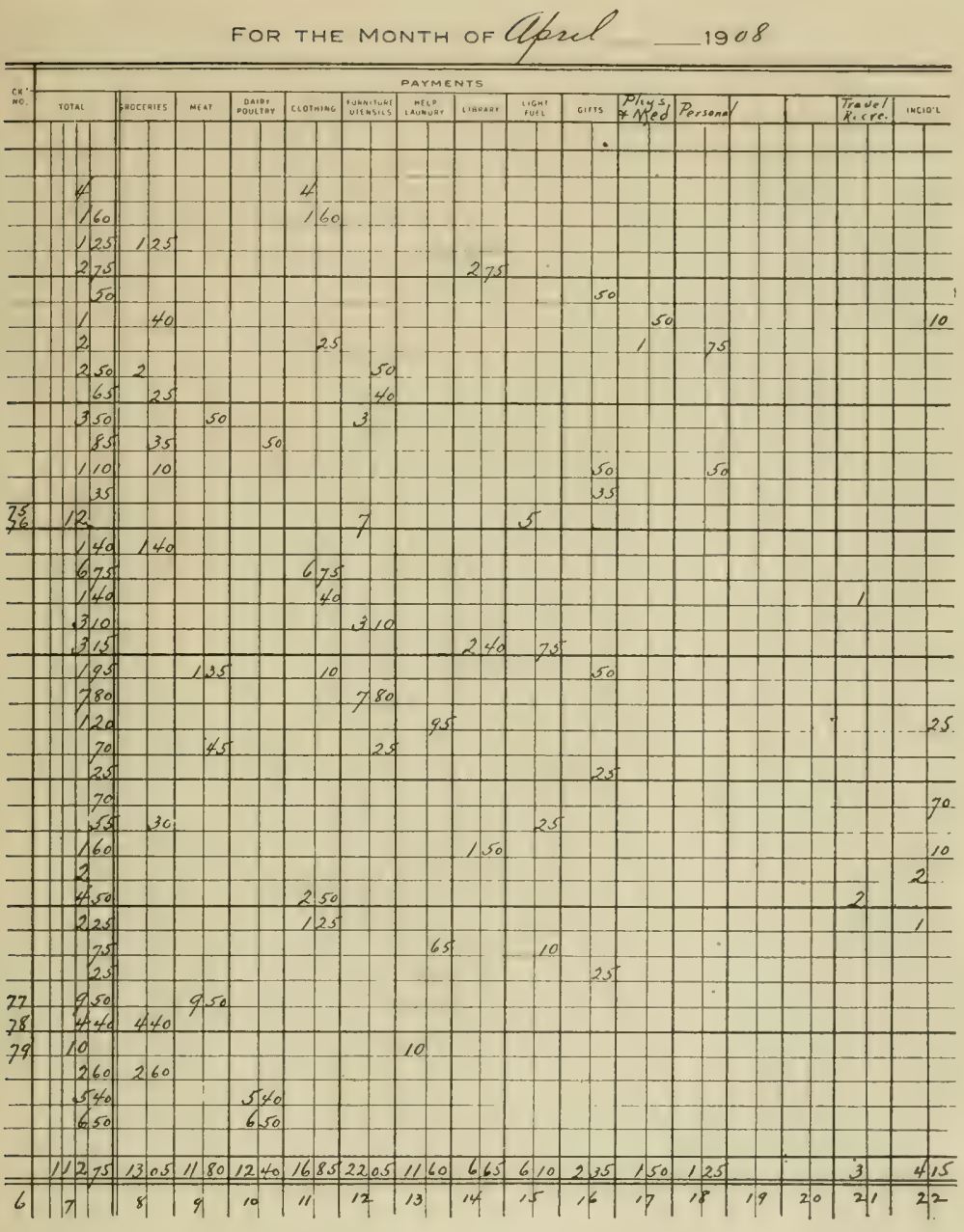

CASH BOOK 
SL:MARY OF HOUSEHOLD ACCOUNTS Hare he 31, 1904.

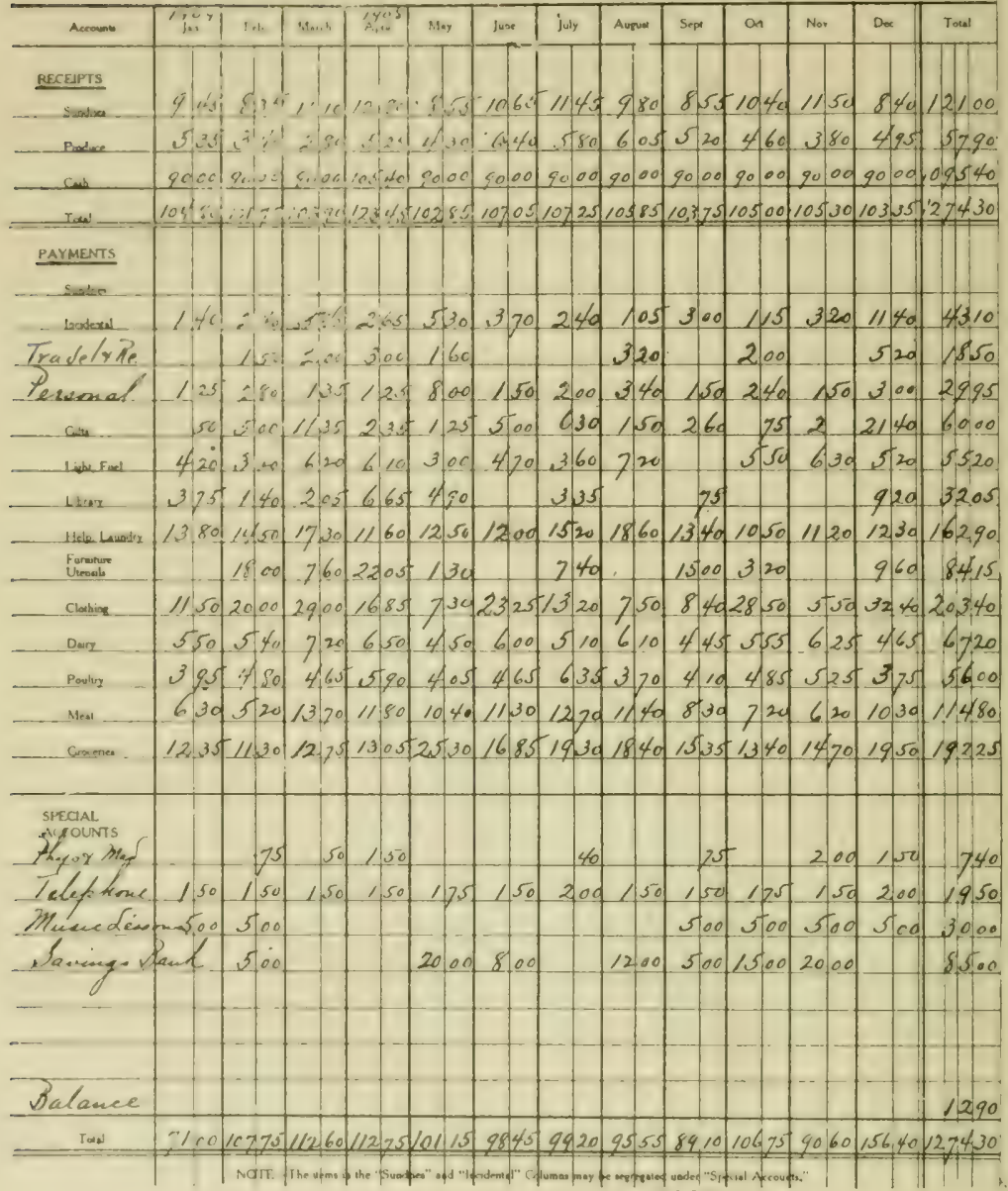

SUMMARY OF HOUSEHOLD ACCOUNTS 


\section{CHAPTER VI.}

\section{THE BALANCE SHEET AND STATEMENT.}

The balance Sheet is a condensed statement of the financial operations for a given period. It exhibits in tabular form the totals of the inventories at the beginning and end of the period; the resources and liabilities; the cash receipts and expenditures; the profits and losses; the net profit or loss and the net worth. It enables the proprietor to analyze his business with considerable accuracy and to trace the sources of profits and losses. There are various forms of the balance sheet, but the following seems best suited to the farming business. For convenience, 1 have shown the results of a month's business only. The inventories are obtained from separate schedules and the cash receipts and expenditures are the totals found in the cash book. The profit and loss columns are made up from figures found in the other columns.

\section{Rules for Finding the Profit or Loss.}

1. Under Resources: To the last inventory add the payments; to the new, add the receipts. If the latter sum is the larger, the difference is a gain; if small, a loss.

2. Under Liabilities: To the new inventory, add the payments; to the last, add the receipts. If the former sum is the larger, the difference is a loss; if smaller, a gain.

\section{Correction of the Profit and Loss Statement.}

From a thoughtful examination of the above balance sheet, it becomes evident that the Profit and Loss statement does not exhibit the actual result of the month's work. The stock account, for example, has been debited only with articles purchased, and credited with returns from animals sold. Labor expended on the stock has not been taken into account; nor has stock been debited with the feed consumed. In order to make the proper corrections, reference is made to the labor and feed records, and the proper charges made. Each accomit is corrected as follows: 


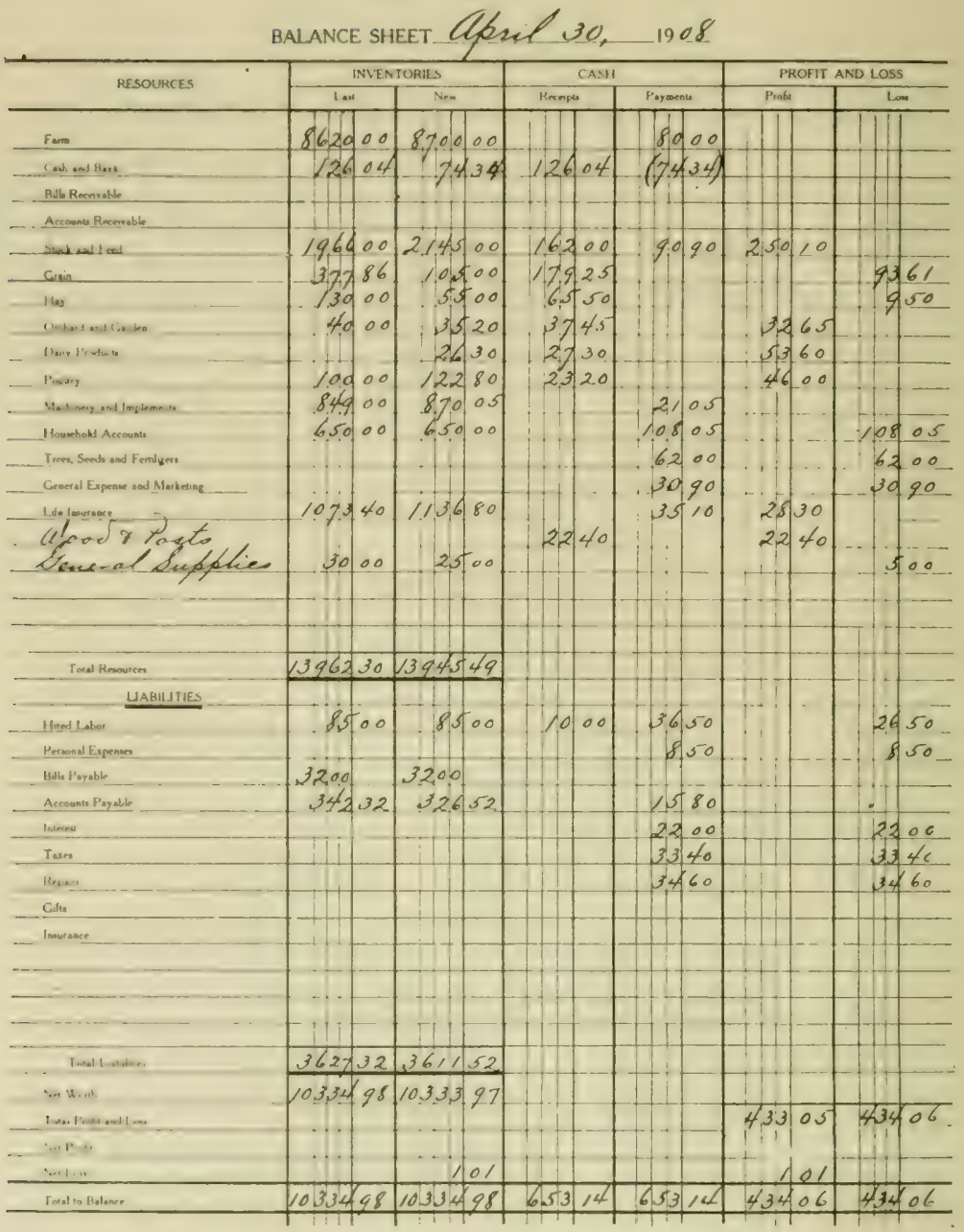

GENERAL BALANCE SHEET 
Stock.

Present Inventory (Bal. Sheet) $\$ 2,145.00$

Receipts.........(Bal. Sheet) 162.00

Total .............. \$2,307.00

Last Inventory (Bal. Sheet. . . \$1,966.00

$\$ 2,307.00$

Payments (Bal. Sheet) ....... 90.90

Labor (Bal. Sheet) . . . . . . . . . 100.00

Grain (Feed Record) ........ 25.00

Hay (Feed Record) ......... 22.00

Int. 1-2 per ct. on $\$ 1,966$ (1 mo.) $\quad 9.80$

Dep. 1-6 per ct. on $\$ 1,966$ ( 1 mo.) 3.25

Total .............. \$2,216.95

Net Gain on Stock..........
$\$ 2,216.95$

$\$ 90.05$

Grain, Hay, Orchard, Dairy, and other accounts of production may be treated in the same manner, if desired. No special book or form is needed for, the above. A page of the Day Book may be used for each account.

\section{Statement for Publication.}

Ordinarily there is no need of preparing any further statement than the Balance Sheet, but since the farmer is frequently called upon to act as treasurer or to consider financial report of either private or public character, I have deemed it advisable to suggest the proper form at this point. Let us suppose that Mr. Harris has an opportunity to sell on condition that he renders a financial statement showing the results of last year's work. The tabular form of the balance sheet would not be readily understood by the average reader, and it is not at all suitable for publication. Following is a convenient and comprehensive form :

\section{Model.}

Statement of the financial condition of the Harris Farm at the close of business, March 31, 1909.

Cash Transactions from April 1, 1908, to March 31, 1909:

\section{Receipts.}

Balance on hand April 1, '08 ... \& 126.04

Stock ................ 1,300.00

Grain ................ 712.43

Hay .................. 204.20

Orchard and Garden........ 335.10

Dairy Products............ 1,018.12

Poultry ............... 262.39

Machinery and Implements sold 60.81

Labor ................. 155.15

Total ............\$4,174.24 \$4,174.24 
Expenditures.

Farm Implements.........\$ 350.00

Stock and Feed............ 445.20

Machinery and Implements.... 225.76

Household Expenses......... 1,074.40

Trees, Seeds and Fertilizers.... 129.71

General Expenses and Marketing 284.39

Life Insurance. . . . . . . . . . . 54.30

Labor .................. 435.70

Personal Expenses. . . . . . . . . 83.40

Accounts Payable........... 252.32

Interest ............... 230.00

Taxes ................. 38.60

Repairs ............... 174.40

Gifts ................. 94.60

Insurance ............. 29.50

Bal. on Hand and in Bank. . . . 271.96

Total ............. \$4,174.24 \$4,174.24

Profits and Losses from April 1, 1908, to March 31,1909.

Profits.

Farm .............. \$ 100.00

Stock ............... 837.30

Grain ................ 714.57

Hay .................. 242.95

Orchard and Garden........ 340.10

Dairy Products............ 1,018.12

Poultry ............... 262.94

Life Insurance........... 9.10

Total ............ \$3,525.08

$\$ 3,525.08$

Losses.

Machinery and Implements .... \& $\$ 60.95$

Household ... . . . . . . . . . . 1,042.00

Trees, Seeds and Fertilizers. ... 129.71

General Expense and Marketing 276.59

Labor ................... 230.55

Personal Expenses........... 83.40

Interest ............... 230.00

Taxes ................... 38.60

Repairs ................ 174.40

Gifts .................. 134.60

Insurance (Fire) .......... 29.50

Net Profit.............. 1,094.78

Total 
Resources and Liabilities.

Resources.

Farm, 160 A. and Buildings. .\$ 9,070.00

Cash and Bank.......... 271.96

Stock .............. 1,948.50

Grain .............. 380.00

Hay ................. 168.75

Urchard and Garden....... $\quad 45.00$

Poultry ............... 100.55

Machinery and Implements. . $\quad 953.00$

Household Accounts....... $\quad 682.40$

Supplies on hand.......... $\quad 37.80$

Paid-up value of Life Ins. . . . 1,136.80

Total ...........\$14,794.76 \$14,794.76

\section{Liabilities.}

Labor Unpaid..........\$ 35.00

Bills Payable............ 3,200.00

rccounts Payable......... 90.00

Church Subscription, Unpaid. . $\quad 40.00$

Net Worth........... 11,429.76

Total ............\$14,794.76 $\$ 14,794.76$ 


\section{COST OF PRODUCTION.}

Too often a good farm is compelled to carry unprofitable experiments and the whole business is pronounced a failure without an adequate attempt to find a remedy. In addition to the foregoing records, Mr. Harris has kept accurate cost accounts of the main branches of his business. In cost accounting there are four principal elements to consider: Cost of material, labor, interest, and depreciation. The cost records a:e independent of all the rest and may be kept of every branch of the business, if desired, or limited to one or more phases. In this instance, cost records have been kept of Live Stock, Grain, Hay, Dairy Products and Improvements. The Agricultural Experiment Stations are always willing to give the farmer important advice and assistance regarding the stock, grain, fruit, etc., best adapted for different localities and purposes. But conditions frequently arise where it is important for the farmer to carry on his own experiments. Your own Experiment Station will doubtless be glad to co-operate and suggest methods for carrying on such experiments even to the extent of furnishing necessary blanks and material. Important bulletins

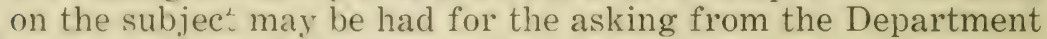
of Agriculture, Washington, D. C.

The following announcement in the Crop Reporter for May, 1908. indicates what the government is doing in this direction:

\section{"Cost of l'roducing Farm l'roducts."}

"The Bureau of Statistics is making an investigation of the cost of producing farm products in different parts of the Inited States. Blank forms have been printed upon which to make reports, and this Bureau desires to receive the names - of such farmers as have kept records of cost of producing crops, or are well informed upon the subject of cost of crop production in their locality, in order that blank schedules may be sent to them to fill in. Individual reports will not be publishedonly the average of many reports. Names should be sent to the Bureau of Statistics, Department of Agriculture, Washington, D. C."

Every farmer should avail himself of this important free service. "Keeping posted" is one of the characteristics of the progressive and successful farmer. There are two exceptionally valuable bulletins on the subject which ought to be in the library of every farmer: U. S. Department of Agricul- 
ture, Bureau of Statistics, Bulletin No. 48, and University of Minnesota, Agr. Ex. Station, Bulletin No. 97.

Live Stock.

Either of three methods may be employed in finding the cost of live stock.

First Method. Ascertain exactly the total amount of grain, hay, and roughage on hand at the beginning of the year, and produced during the year. From this subtract the quantity sold, including amount used by household and for seed, and the amount on hand at the end of the year. The difference is the quantity used for live stock. The value at market prices is the expenditures of feed for live stock.

Find the total amount received for dairy products, including amount used by the household. The difference between the cost and the receipts is the gain. The disadvantages of this method is that no account is taken of individual animals nor of different kinds of stock. The herd as a whole may be a paying investment and still there may be individual animals carried at a loss. It is desirable that such records be kept, at least occasionally, as will enable the farmer to eliminate unprofitable animals.

Second Method. The following actual record of a dairy herd of twelve cows illustrates a mach more satisfactory test than the preceding. Individual record was kept of the milk produced by each cow, but the feed was weighed for the entire herd, and the average cost charged to each animal at market prices.

With this average before him, a careful feeder will be able to make mental corrections for each individual animal, accurate enough for most practical purposes. The milk record has been kept, as illustrated on page 46 .

Tests of Dairy Herd for March, 1909.

\begin{tabular}{|c|c|c|c|c|c|c|}
\hline $\begin{array}{l}\text { No. } \\
\text { Cow } \\
1 .\end{array}$ & $\begin{array}{c}\text { Lbs. Milk } \\
\text { for Mo. } \\
465\end{array}$ & $\begin{array}{c}* \text { Test. } \\
4.5\end{array}$ & $\begin{array}{c}\text { Lbs. } \\
\text { Fat. } \\
20.93\end{array}$ & $\begin{array}{c}\text { Val. at } \\
36 \mathrm{c} . \\
\$ 7.53\end{array}$ & $\begin{array}{l}\text { Cost of } \\
\text { Feed. } \\
\$ 6.21\end{array}$ & $\begin{array}{c}\text { Net } \\
\text { Profit. } \\
\$ 1.32\end{array}$ \\
\hline 2. & 372 & 5.0 & 18.60 & 6.70 & 46 & .49 \\
\hline 3. & 620 & 5.0 & 31.00 & 11.16 & "6 & 4.95 \\
\hline 4. & 372 & 7.0 & 26.04 & 9.37 & 6 & 3.16 \\
\hline 5. & 496 & 4.8 & 23.80 & 8.57 & “6 & 2.36 \\
\hline 6. & 682 & 4.7 & 32.05 & 11.54 & 66 & 5.33 \\
\hline 7. & 558 & 4.4 & 24.55 & 8.44 & 6 & 2.23 \\
\hline 8. & 620 & 4.1 & 25.42 & 9.15 & 66 & 2.94 \\
\hline 9. & 496 & 4.2 & 20.83 & 7.50 & 66 & 1.29 \\
\hline 10. & 651 & 4.9 & 31.90 & 11.48 & 6 & 5.27 \\
\hline 11. & 558 & 5.0 & 27.90 & 10.04 & 6 & 3.83 \\
\hline 12. & 589 & 5.0 & 29.45 & 10.60 & 66 & 4.39 \\
\hline
\end{tabular}


Feed for the Month of March.

Hay, 4,900 lbs. at $\$ 9.00$ per ton.......... \$22.05

Kale, 9,600 lbs. at $\$ 2.50$ per ton......... 12.00

Bran, 1,800 lbs. at $\$ 30.00$ per ton . . . . . . 27.00

Shorts, $900 \mathrm{lbs}$. at $\$ 30.00$ per ton......... 13.50

Total

$\$ 74.55$

74.55 divided by 12 equals 6.21 , average cost of feed.

Third Method. The difference between the second and third methods is that in the latter accurate records are kept of individual feed rations, while in the second method an average is taken. The error resulting from averaging the feed between alı the animals in a large herd may be such as to unduly favor curtain animals and do injustice to others. The only absolutely accurate method is to keep an account with each animal; at least with such animals as show a tendency to be unprofitable. Page 43 shows an individual account with one of the milch cows on the Harris farm. It is arranged on the regular ledger form. Opposite pages of the Day Book may also be used. The detailed information regarding Feed, Milk, Labor, etc., is found in the respective records, illustrated on pages 46 and 47 respectively. Similar accounts are kept of each animal, tested preferably during the entire lactation period. It is only in this way that the careful farmer can determine whether each animal is kept at a gain or a loss. The weeding out of one or two unprofitable animals a year will pay for the labor of keeping the cost records many times over.

\section{Cost of Crops.}

The principles laid down in respect to the cost of animal products hold true also for the cost of farm crops. Two methods suggest themselves. Accounts with the various crops and accounts with the different fields. Either method requires detailed records of the labor, seed, fertilizer, etc., extended on the crop and of returns not only for cash sales, but for products used by the household and for feed. On page 43 is illustrated an account with the wheat crop in 1908. Only one item needs explanation, that of depreciation due to continuous cropping. Whether the rate, two per cent, is too high or too low, matters little; the important point to be emphasized is that the value of the land diminishes unless rotation of corps is practiced .

* These figures were obtained by the Babcock test, which is described in every modern work on dairying. 
Peanl (Daing cow)
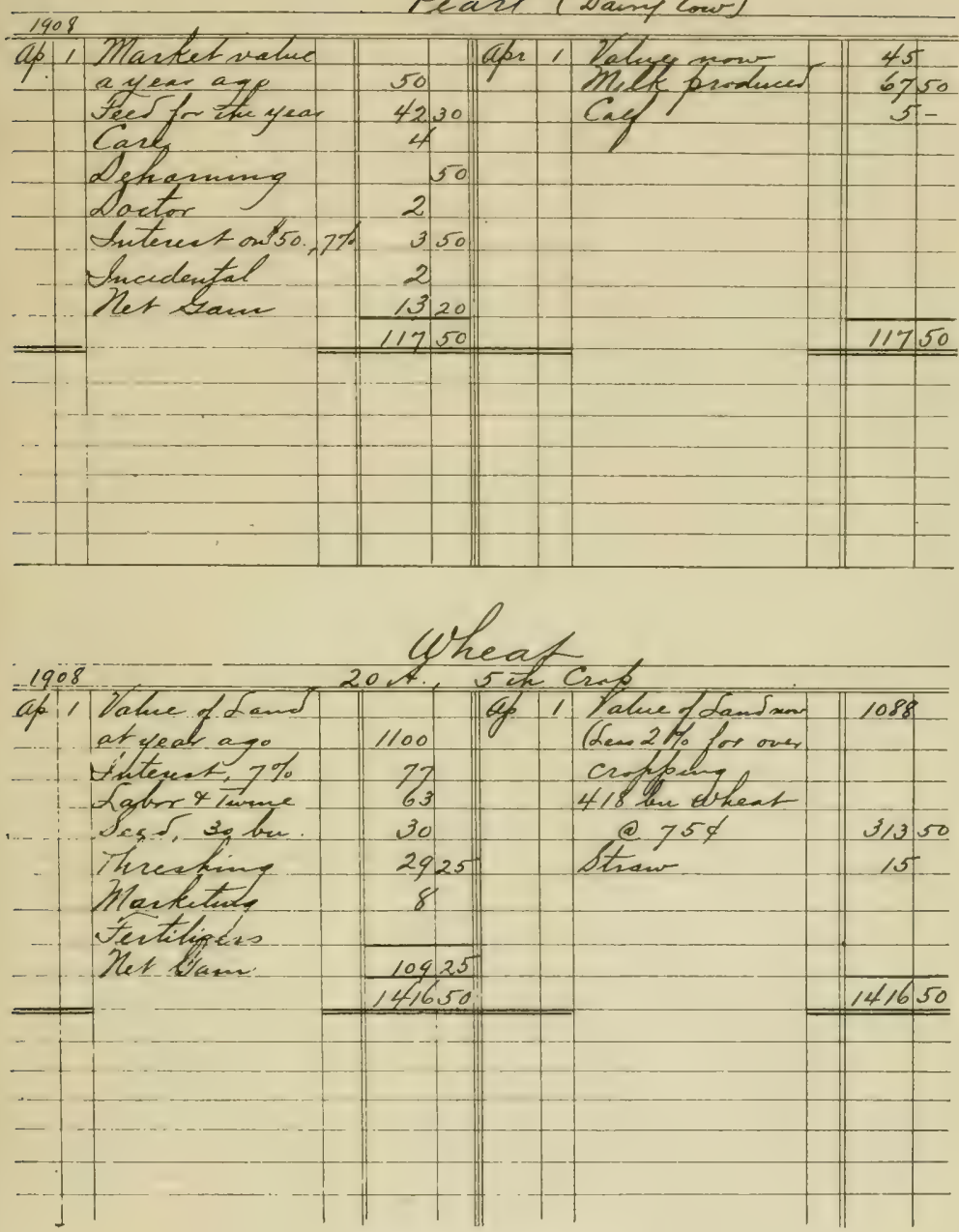

COST ACCOUNTS 


\section{SPECIAL RECORDS.}

There are several convenient special records which ought to he adopted, besides those I have illustrated. It is not necessaly that expensive printed books be provided. A plain sheet of paper may be ruled as suggested below and pasted in the Bill File. In fact, this is in many respects preferable to printed forms, because the forms can then be changed from year to year to suit conditions. I illustrate only the following:

\section{Isabor Records.}

The best form of a labor record is illustrated on pages 46 and 4.. In one, account is kept with the object upon which labor is expended; in the other, with the laborer. For ordinary purposes, page 46 is the most convenient, but where several men are engaged on a project, form (a), page 48, is preferable

\section{Milk Records.}

Two milk records are illustrated on pages 46 and 48. Each possesses certain advantages over the other. The weekly record need not be so large and admits of larger space, while the monthly record exhibits the entire month's result on a single page. The weekly record is more appropriate for filing, being less liable to soiling. Whichever form is used, it should be tacked to a board in a convenient place for the milker. A spring scale, graduated to hundredths, should be hung near the record, far enough from the wall for the pail to hang freely. The original records should be filed for at least a year. If a daily time book is kept, it may aiso be adapted for the milk and poultry records.

\section{Poultry lecords.}

Practically the same form as the milk record can be used conveniently for the Egg record, and it is not deemed necessary to enlarge further on the subject.

The methods of improving the poultry stock, and other usefil information regarding the poultry business, is found in nimerous books and bulletins on the subject.

\section{Duplicating Sales Book.}

It is often convenient to retain a duplicate of sales, order's, receipts, etc. It will be found very helpful to the farmer and to the dealer alike, if the farmer prepares a bill of the produce he brings into town for sale. This will often avoid misunder- 
standing, and may save money. This is especially true if the produce is sent in by children or by someone not connected with the family. On page 48 is illustrated a very convenient book which is kept in stock in most stationery stores. Where this system is used, it is advisable that every sale be recorded, and then listed as shown on page 47. In entering in the Cash Book, the sale number should be inserted. All sales to merchants should be considered as cash, even if the produce is erchanged for merchandise. If sales are made on time, note the fact on the bill, and enter it into the personal account as illustrated on page 19 .

\section{The Farm Plot.}

There is one more record which I cannot urge too strongly. I refer to the yearly plots. This record will prove to be one of the most valuable and interesting parts of the farm history. A plot is easily made by first drawing a square on a blank prece of paper and then sketching the fields. It is, of course, unnecessary to draw this to scale. A close approximation is all that is necessary. Following is an illustration:

\section{Office Methods.}

Talk about office methods on the farm! Why not? Why should not the average farmer enjoy at least a comfortable desk and neatly printed stationery? Every boy loves "to do business." Surround him with a business atmosphere on the homestead and he will stay by you and succeed you in your old age; continue in your slip-shod methods and he will move to town and become a $\$ 40$ clerk instead of a landed proprietor. Encourage your children to assist in your business; make them feel that they are intimately associated with you. Take them into your confidence and, as they grow older, into your counsel, especially when you are considering your annual bulance sheet and a greater prosperity, wider influence, and a more contented family will be your reward. 


\section{MILK RECORD}

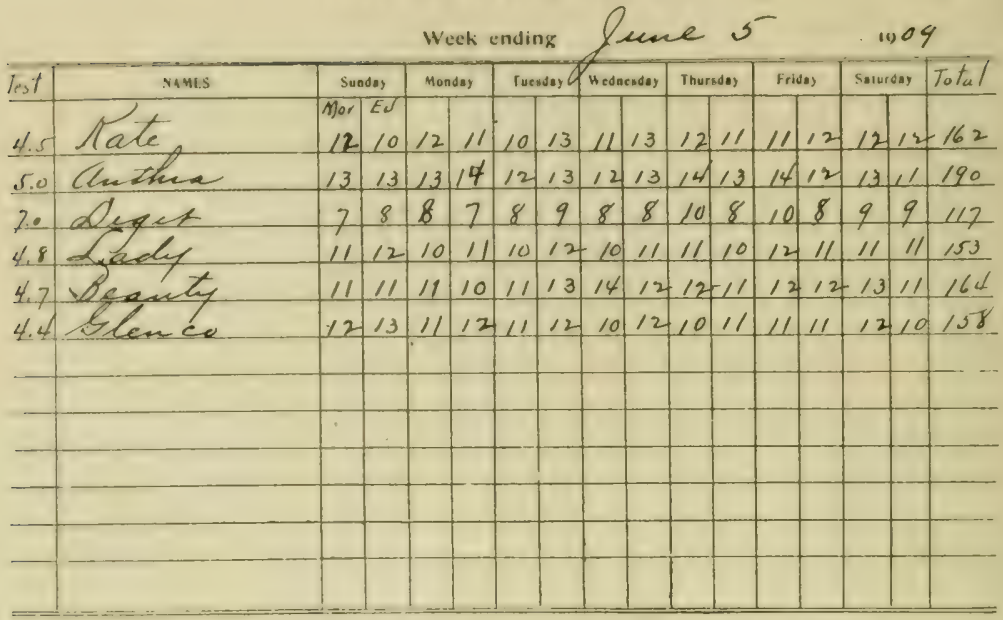

(u) Feed Record. Daury Gours, Gune 1909

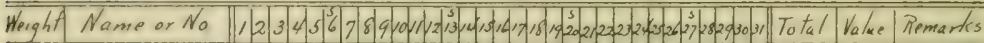

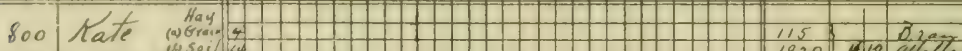

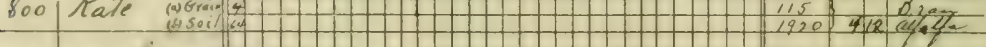

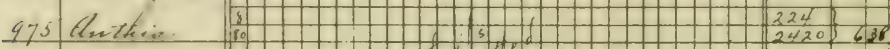

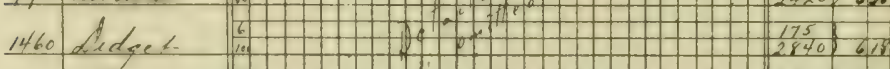

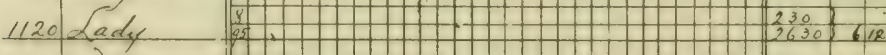

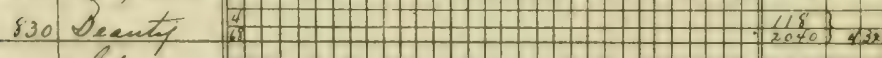

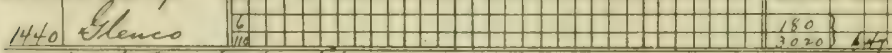

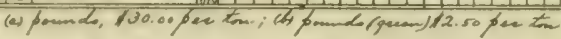

(4)

$$
\text { Dacly Labor Record, Gune, } 1909
$$

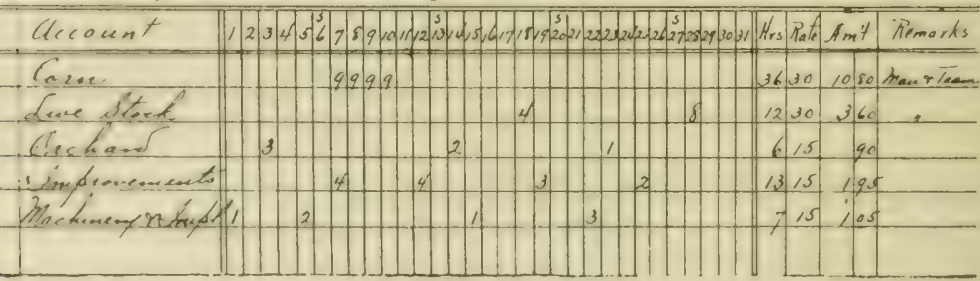



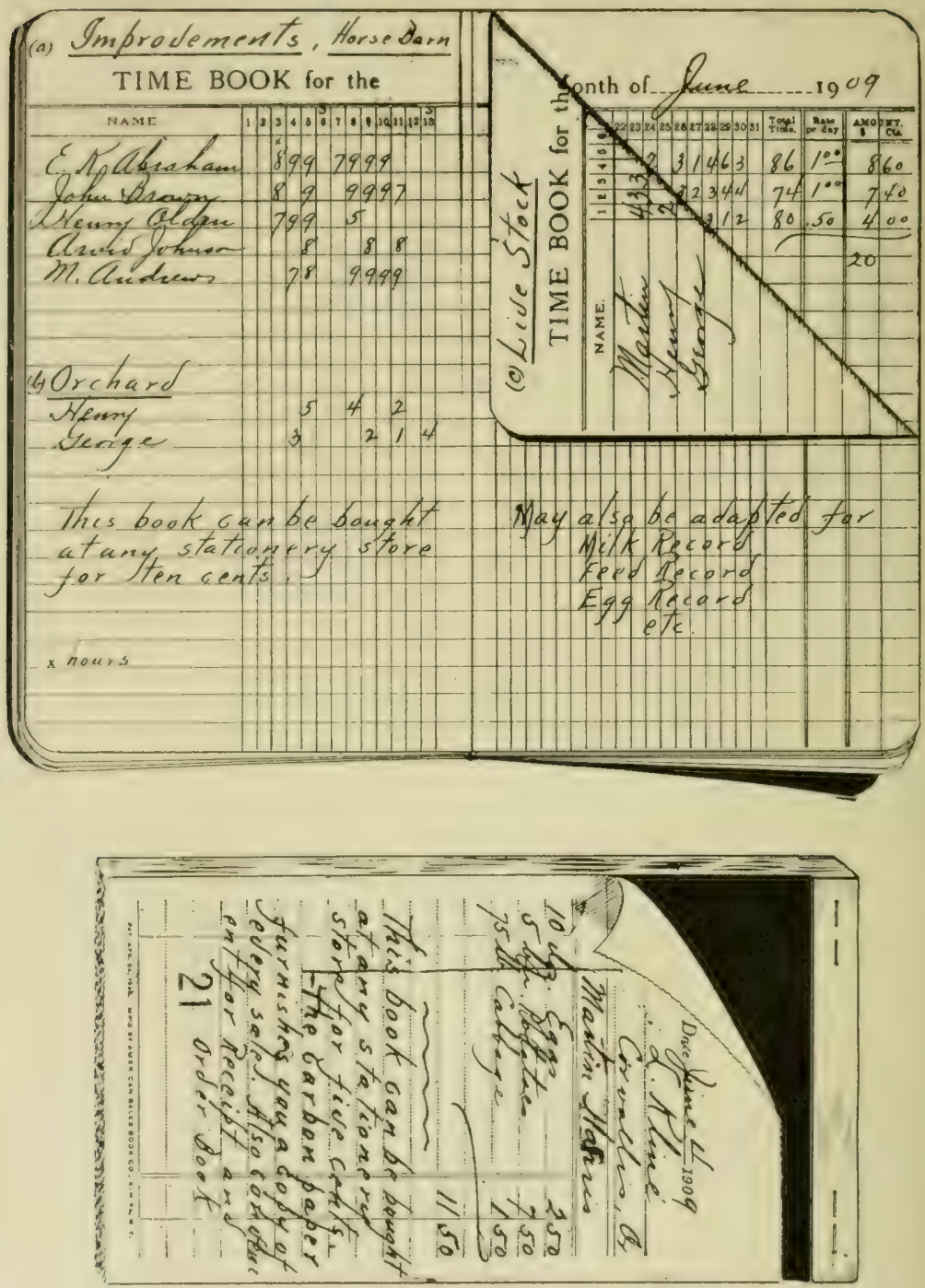

TIME AND SALES BOOK 


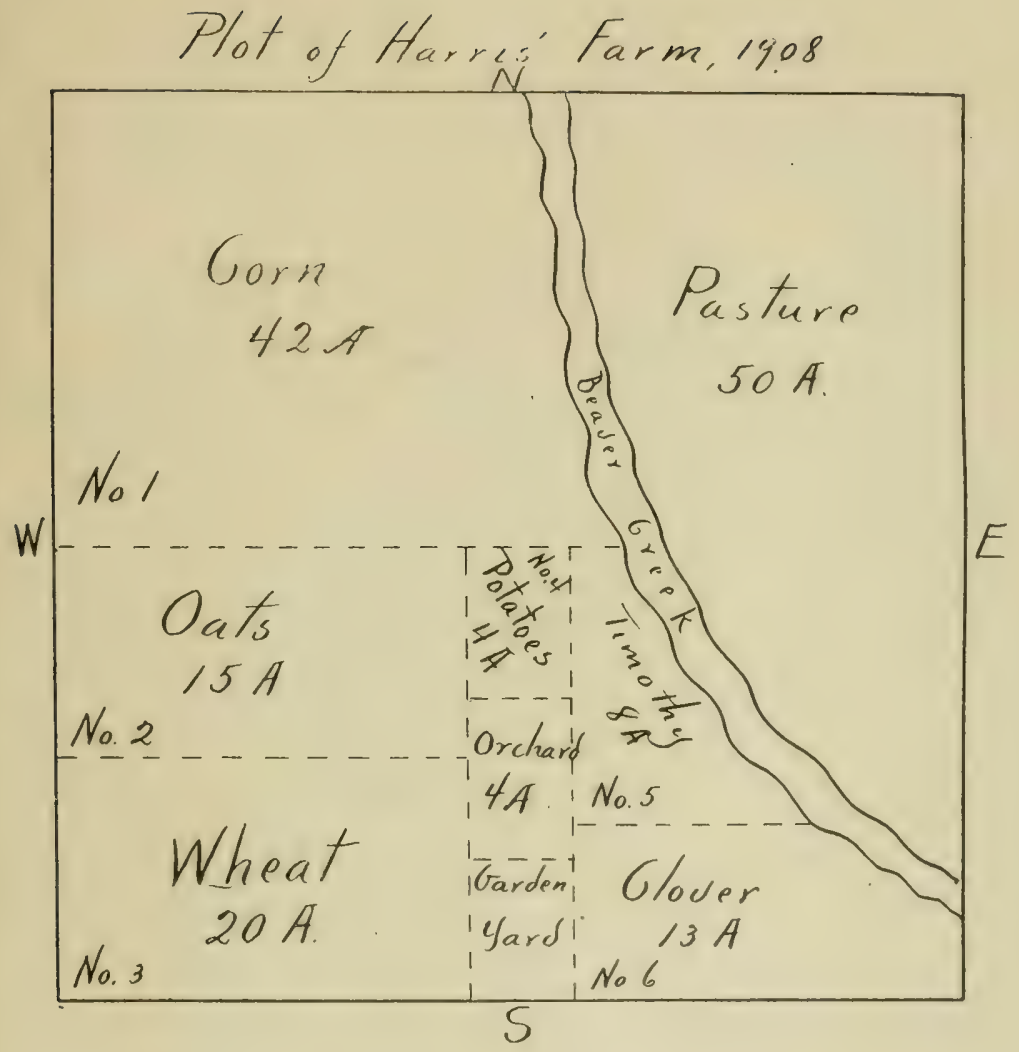

THE FARM PLOT 


\title{
CIIA I'ISIR IX.
}

\section{IRACTICE WORK IN SINGLE ENTRY.}

\author{
LESSON 1.
}

THE DAY BOOK.

Step 1. Number the pages of all your books.

Step 2. Write at the top of page 1, of you Day Book: Monday, April 1, 19-. Then copy in your Day Book the following opening statement: (All work must be done neatly in ink on forms prescribed by your teacher.)

Directions.

Six vears ago to-day I purchased my present farm, investing, cash, $\$ 6,000$. Below is an accurate inventory of all my prop$e_{i} \mathrm{t} y$, and a statement of $\mathrm{my}$ affairs as they stand today.

Step 3. Skip one line, then arrange the following statement of Resources and Liabilities exactly as illustrated on page 15:

\section{Inventory, April 1, 19-.}

Resources: Farm, 160 A.; with buildings, $\$ 8,000$. Produce: $200 \mathrm{bu}$. Corn at $50 \mathrm{c} ; 150 \mathrm{bu}$. Oats at $45 \mathrm{c} ; 200 \mathrm{bu}$. Wheat at $85 \mathrm{c} ; 20$ tons Hay at $\$ 6$; Potatoes and Vegetables, $\$ 50.00$. Stock: 6 Horses, average $\$ 100.00 ; 20$ Cows, average $\$ 40.00$; 11 steers, average $\$ 12.00 ; 5$ Heifers, average $\$ 11.00 ; 12$ Hogs, average $\$ 6.00 ; 100$ Sheep, average $\$ 3.00$. Poultry: 150 Chickens at $15 \mathrm{c} ; 21$ Turkeys at $75 \mathrm{c}$. Implements: 1 Binder, $\$ 125.00 ; 2$ Plows at $\$ 10.00 ; 2$ Harrows at $\$ 12.50 ; 1$ Mower, $\$ 10.00 ; 1$ Hay Rake, $\$ 15.00 ; 1$ Grain Drill, $\$ 50.00 ; 2$ Wagons, $\$ 110.00$; 2 Sets Harness, $\$ 90.00$; 1 Buggy, $\$ 100.00$; Tools, $\$ 50.00$. Supplies, $\$ 25.00$; Household Goods, $\$ 350.00$; Life Insurance (paid-up value), $\$ 964.36$; Cash, $\$ 170.00$.

Lial)ilities: Labor (unpaid). $\$ 75.00$; Accounts Payable, $\$ 125.15$; Nortgage, favor Iowa Trust Co., $\$ 3,000.00$.

Step 4. Hand in your work for approval.

\section{LESSON 2.}

\section{DAY AND CASH BOOK COMBINED.}

('opy the following entries in the Day Book on the next page following the last statement. (See page 12.)

Head the pages and columns the same as in illustration.

IIonday, April 1, Cash on hand, $\$ 170.00$. (Received Column.) 
Monday, April 1, 1908, Heavy rain storm. Shod Cap and Maud at Scowscroft's. Paid $\$ 3.00$. Bought two tons of coal at $\$ 4.00$.

Tuesday, April 2. (Skip a line between each date.) Attended Breeders' Convention at Portland. Program and report pasted on page 16 in Bill File. Paid expenses $\$ 8.40$.

Wednesday, April 3. Paid grocery bilı at Murdock's. Bill on file, page 16:- $\$ 11.40$.

Thursday, April 4. Bought milch cow of J. C. Smith. Paid Cash $\$ 40.00$.

Attended concert of the Boston Jubilee Singers, with family. Paid expenses, $\$ 2.00$.

Friday, April 5. Sold one calf to P. A. Anderson for Cash, $\$ 7.00$. Bought 1 pair Gloves, $\$ 1.50$.

Saturday, April 6. Bought at La Fount's for Cásh: 1 Ax $\$ 1.00,1$ Hammer 45c, Nails 50c; Total $\$ 1.95$.

Went to Portland to select Farm Implements. Expenses, $\$ 3.00$.

Sunday, April 7. Attended church with family; Dr. E. Hamilton preached on "Civic Honor.' Collection 25c.

Tuesday, April 9. Bought shoes for Teddie, $\$ 2.00$.

Wednesday, April 10. Bought 5 bu. tested seed corn at $\$ 2.00$.

Thursday, April 11. Rain all day. Fannie dropped calf.

Friday, April 12. Sold 3-year-old horse, Cap, for $\$ 125.00$.

(The names of days may be omitted or continued.)

April 13. Bought 1 Studebaker Top Buggy. Price $\$ 135.00$, discount $\$ 15.00$. Net amount paid, $\$ 120.00$.

April 14. Attended church with family. Our pastor preached on "The Prodigal Son." Collection 25c. Paid quarterly dues, $\$ 10.00$.

April 15. Mother took sick suddenly. Dr. Brown considers her case very serious.

April 16. Hired Frank Johnson for six months at $\$ 30.00$ per month and board. Mother is better.

April 17 to 28. Student will insert at least one imaginary entry for each date. Try to use good judgment as to what might happen and what might be purchased and sold during this month. Be careful not to pay more money than you have received.

April 29. Paid the following bills: Skinner Bros., Dry Goods. Bill pasted on page 17, Bill File, $\$ 14.50$; Murdock's, Groceries. Bill File, $\$ 15.60$.

Sold Murdock's 20 doz. Eggs, at 20c; 12 Dressed Spring Chickens at $30 \mathrm{c}$.

April 30. Received cream check. See statement Bill File, page $18, \$ 45.30$. 
You will now add the "Received" and "Paid" columns and find the Cash on hand. Hand in your work for approval.

LESSON 3.

SPECIAL CASH BOOK.

As stated on page * it is often convenient to lieep a separate Cash Book instead of entering all the Cash transactions in the Day Book. For the sake of practice, you may now prepare a Cash Book with the same cash entries as given in the Day Book above. The form is shown on page * .

Hand in your work for approval.

LESSON 4.

PERSONAL ACCOUNTS.

Read the remarks regarding personal accounts on page 20 . Turn to near the end of your Day Book and prepare two sets of accounts, one entitled "Others Owe Us" and another "We Owe Other's."

(1) "Others Owe Us." Mrs. Richard King, a neighbor, has been buying dairy and poultry products on account. Her' alccount is illustrated on page 19. Prepare a similar account with the following entries: We charge her:

May 1. There was a balance due from April, $\$ 3.80$; May 1 , 1 lb. Butter 20c; May 3, 2 doz. Eggs at 15c; May 5, 1 chicken $30 \mathrm{c}$; May 12, 2 lb. Butter 20c; May 18, 2 qts. Strawberries 30c; May 25, 1 qt. Cream 20c; May 31, 1 lb. Butter 20c.

May 31. She paid cash $\$ 5.00$.

Balance the account as illustrated.

In a similar manner prepare an account with the Adams Mercantile Co., with whom we are trading and who are buying produce from us. We charge them:

June 4. 5 bu. Potatoes at $75 \mathrm{c} ; 60$ bunches Onions, 40c doz.; 10) doz. Sweet Corn at 20c. On the same date we bought groods as per their bill, pasted on page 17 in the Bill File, \$6.50.

- We charge, June 15,8 crates Strawberries at $\$ 1.75 ; 20$ doz. Eggrs at 15c. On the same date we bought a suit for William for $\$ 15.00$. Prepare this account, rule and balance the same as Mrs. King's account. The balance due us is $\$ 5.25$.

In a similar manner prepare three additional original accounts of not less than ten entries to each.

(2) "We Owe Others." Frank Johnson, one of the farm hands, has requested that his wages be left on account, and that he be allowed to draw as he needs from time to time. The following items enter into his account. Prepare it exactly the same as the five preceding accounts. April 30, wages for April, $\$ 30.00$; May 1st, paid him cash, $\$ 10.00$; May 5 th, bought clothing for him at Goddard's \$7.20; May 10th, 
cash $\$ 5.00$; May 20th, eash $\$ 3.00$; May 31st, wages for May $\$ 30.00$. Rule and balance as heretofore.

On July 1st you bought a 3-year-old horse "Jim" for $\$ 150$. on condition that it was to be paid for at the rate of $\$ 25.00$ per month. Four payments have been made on the first of each month, beginning August 1st. Write up the account. Rule and balance as heretofore.

Prepare three additional original accounts, as above.

\section{LESSON 5 .}

FINANCIAL STATEMENT No. 2, APRIL 1, 19 -.

We have now arrived at the end of the year and we are ready to prepare the second financial statement.

Directions.

Step 1. Take inventories of all the property, listing and placing a fair valuation on it, same as in Lesson 1.

Step 2. Go through your personal accounts, balance them as illustratea in Lesson 4, and extend the amounts under the various headings in the inventory, Grain, Stock, etc.

Step 3. If you own any notes, stock or other valuables, list them under Bills Receivable. Be sure not to omit anything you own or owe.

The above directions merely indicate how an inventory is taken. The following inventories are assumed and you will merely prepare a statement exactly the same as in Lesson 1. Be sure to arrange heading, etc., exactly as heretofore. Compare the values and find totals. See page 17.

Inventory, April 1, 19-.

Resources.

Farm, $\$ 8,620.00$. Produce: 150 bu. Corn at 55c; 175 bu. Oats at $43 \mathrm{c} ; 253 \mathrm{bu}$. Wheat at $87 \mathrm{c} ; 20$ tons Hay at $\$ 6.50$; Potatoes and Vegetables, $\$ 40.00$. Stock: 6 Horses at $\$ 100.00 ; 1$ 3 -year-old horse, "Jim," $\$ 150.00 ; 22$ Cows at $\$ 42.00 ; 14$ Steers at $\$ 13.00 ; 4$ Heifers at $\$ 11.00 ; 11$ Hogs at $\$ 6.00$. Poultry : 165 Chickens at $45 \mathrm{c} ; 25$ Turkeys at $75 \mathrm{c} ; 10$ Geese at $70 \mathrm{c}$. Implements: 1 Binder, $\$ 120.00$; 2 Plows at $\$ 18.00 ; 2$ Harrows at $\$ 20.00 ; 1$ Mower at $\$ 40.00 ; 1$ Hay Rake at $\$ 13.00 ; 1$ Grain Drill, $\$ 45.00 ; 2$ Wagons, $\$ 40.00$ and $\$ 60.00 ; 1$ New Wagon, $\$ 100.00 ; 2$ Sets Harness, $\$ 25.00$ and $\$ 65.00 ; 1$ Surrey, $\$ 165.00$; 1 Light Buggy, $\$ 50$; Tools, $\$ 50$. Supplies, $\$ 30.00$. Household Goods, $\$ 350.00$. Piano, $\$ 300$. Life Insurance, $\$ 1073.40$. Cash and Bank, $\$ 126.04$.

Liabilities.

Labor, unpaid, \$85.00. Accounts Payable, $\$ 142,32$. Mort- 
gage, favor Iowa Trust Co., \$3,000.00. Note, favor Western Lumber Co., \$200.00. Due on Piano to Smith Bros., \$200.00. Having completed the statement of Resources and Liabilities you will now determine the profits for the yar. Skip one line and write the following statement, inserting the net worth in Statement No. 1 and what you find above.

\section{statement of Protits and locsices.}

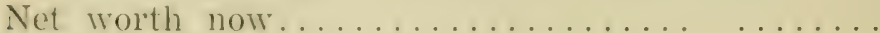

Net worth last year.

Net profit

Your result will agree with the illustrat in on page 17 , if colrect. Dividing the gain with last year's net inventory we find that you have made a gain of about 9 per cent on your investment and labor. 
CHAITHR $x$.

\section{PRACTICE WORK IN DOUBLE ENTRY.}

The last year has demonstrated the value of bookkeeping, but the Profit and Loss statement is very unsatisfactory. The entire business shows a profit of $\$ 851.02$, but it is impossible to show from the records the sources of the profits and losses. George will continue keeping the books, for which he will receive $\$ 5.00$ per month, but we have decided to use double entry next year. Ninety dollars per montn, payable three times per month, and produce, will be allowed for household and personal expenses as suggested on page 29.

LESSON 6 .

\section{HOUSEHOLD ACCOUNTS.}

Following are the Household Receipts and Expenditures for the Month of April, 1908:

April 1. Balance forwarded, $\$ 15.40$; on Allowance, $\$ 30.00$; Shoes for Mabel, $\$ 3.00 ; 2$ Vests, $\$ 1.00 ; 10$ yds. Muslin at $10 \mathrm{c}$; 4 yds. Gingham at $15 \mathrm{c}$.

3. Sugar, $\$ 1.00$; Raisins, 25c; subscription to Successful Farming, $\$ 1.00$; subscription to Ladies' Home Journal, $\$ 1.75$.

5. Collection, 25c; Ladies Aid Society, 25c; 2 doz. Eggs, 40c; Medicine, 50c; Stove Polish, 10c.

6. Doctor, $\$ 1.00$; Ella, 25c; George, 50c; Necktie for Jim, $25 \mathrm{c} ; 5 \mathrm{bu}$. Potatoes at $40 \mathrm{c}$; Skillet, $50 \mathrm{c}$.

8. 5 Cabbage, $25 \mathrm{c}$; Bread Knife, 40c; Meat, 50c; Parlor Lamp, $\$ 3.00$.

9. 3 lbs. Crackers, $25 \mathrm{c}$; Peanuts, 10c; Eggs, 50c ; to boys for ball game, 50c; Starch, 10c; Relief Society, 50c.

12. Collection, $35 \mathrm{c}$.

13. Rocker, $\$ 7.00$; Prunes, $\$ 1.00$; on Allowance, $\$ 30.00$; Coal, $\$ 5.00$; Vegetables, $40 \mathrm{c}$.

14. Suit for William, $\$ 6.00$; Hat for George, $75 \mathrm{c}$; Concert, $\$ 1.00 ; 2$ yds. Ribbon, $40 \mathrm{c} ; 1$ doz. Plates, $\$ 2.20$; one-half doz. Cups and Saucers, 90c.

15. School books and stationery, $\$ 2.40$; Kerosene, $75 \mathrm{c}$; Ham, $\$ 1.35$; Sociable, 50c; Shoe Strings, 10c.

17. Kitchen Cabinet, $\$ 6.50 ; 2$ Chairs, $\$ 1.30$; Laundry, $95 \mathrm{c}$; Toilet Soap, 25c; 3 lbs. Fish, 45c; Towel Rack, $25 \mathrm{c}$.

19. Collection, $25 \mathrm{c}$.

20. 6 yds. Toweling, 60c; Tacks, 10c; 1 gal. Vinegar, 30c; 
Matches, 25c; White House Cook Book, $\$ 1.50$; Carbolic Acid, $10 \mathrm{c}$.

23. Telegram to M. F. \& Co., 50c; Telephone Rental, $\$ 1.50$; Mrs. Sloan for Dressmaking, $\$ 2.50$; Madrid and return, $\$ 2.00$.

25. $1 \mathrm{pr}$. Rubbers, 75c; Stockings for Ella, 50c; Flowers for Mrs. Knox's Funeral, $\$ 1.00$; Allowance, $\$ 30.00$; Laundry, 6äc; Lamp Wicks, 10c.

26. Collection, 25c.

29. Meat, Lity Market, as per Bill File, $\$ 9.50$; Groceries at Murdock's, as per Bill File, $\$ 4.40$; Help for the Month, $\$ 10.00$.

30. Vegetables for the month, $\$ 2.60$; Poultry, $\$ 5.40$; Milk, Cream and Butter, $\$ 6.50$.

Directions.

Step 1. Enter in the household record and distribute in the proper columns, as illustrated on page 32. The first twelve days are given exactly as they will appear in your books, if correct.

Step 2. Add all the columns (Use lead pencil until you have proved your work). If your work is correct, you will find the following totals: Receipts: Cash, $\$ 105.40$; Produce, $\$ 5.25$; Dairy and Poultry, $\$ 12.80$. Payments: Groceries, $\$ 12.65$ (correction, line $8,40 \mathrm{c}$ ) ; Meat, $\$ 11.80$; Dairy and Poultry, $\$ 12.80$; Clothing, $\$ 16.85$; Furniture and Utensils, $\$ 22.05$; Help and Laundry. $\$ 11.60$; Library, $\$ 6.65$; Medicine and Physician, $\$ 1.50$; Light and Fuel, $\$ 6.10$; Gifts, $\$ 2.35$; Personal, $\$ 1.25$; Traveling and Recreation, $\$ 3.00$; Incidental, $\$ 4.15$.

LESSON 7 .

\section{FARM RECEIPTS.}

In the same manner as in Lesson 6, you may proceed to enter Cash Rereipts for April, 1908. See form on page 22. Your entry wili be exactly like the illustration, if correct. Observe that each amount is entered twice: (1) In the total column, and (2) in the distribution columns. Hence the term "Double Entry."

April 1. Balance forwarded, $\$ 126.04$. (Total and Sundry Columns.)

1. 2 tons Clover at $\$ 6.00 ; 80$ bu. Corn at $65 \mathrm{c}$.

3. 1 doz. Cabbage at $10 \mathrm{c} ; 25 \mathrm{lbs}$. Butter at $25 \mathrm{c}$.

6. 2 Steers at $\$ 40.00 ; 20$ Spring Chickens at $45 \mathrm{c}$; Hauling Coal, 1 day, $\$ 5.00$.

9. Jersey Calf, $\$ 10.00 ; 2$ colds Wood at $\$ 4.00 ; 5$ bu. Potatoes at $\$ 1.00$.

12. Heifer, $\$ 25.00 ; 10 \mathrm{lbs}$. Butter at 281/2c.

13. 75 bu. Corn at $65 \mathrm{c}$; Work on County Road, $\$ 5.00 ; 4$ bu. Apples at $\$ 1.50$. 
15. 201/2 doz. Eggs at 20c; 36 lbs. Butter at 25c; 2 tons Clover at $\$ 6.00$.

1\%. 100 Apple Trees at 20c; 1 Steer, $\$ 37.00 ; 12$ Cedar Posts at $20 \mathrm{c}$.

19. 6 Spring Chickens at 40c; 95 bu. Corn at 60c; 3 tons Hay at $\$ 6.00$.

20. Jersey Calf, $\$ 10.00 ; 50$ bu. Oats at $35 \mathrm{c}$.

23. 1 Turkey, $\$ 1.40 ; 1$ bu. Clover Seed, $\$ 1.50$.

26. $18 \mathrm{lbs}$. Cheese at $15 \mathrm{c}$.

29. 3 Cords Wood at $\$ 4.00 ; 10$ bu. Barley at $40 \mathrm{c} ; 4$ tons Timothy at $\$ 5.50$.

30. Produce for Household Use: Orchard and Garden, $\$ 5.25$; Dairy, $\$ 6.50$; Poultry, $\$ 6.30$.

Directions.

Step 1. Turn to page 2 in your Cash Book and enter the preceding items in the proper columns.

Step 2 Add the columns. The correct results are as follows : Total, $\$ 650.54$; Grain $\$ 79.25$; Hay, $\$ 65.50$; Orchard and Garden, $\$ 34.85$; Stock, $\$ 162.00$; Dairy, $\$ 27.30$; Poultry, $\$ 23.20$; Sundries, $\$ 158.44$.

Note that the total of the distribution columns equals the total column.

Step 3. The Sundry column contains the following items:

Balance April 1st. . . . . . . . . . . . . \$126.04

Labor

10.00

Wood

22.40

Total

$\$ 158.44$

Verify the above by setting down each item under its appropriate head and adding. Arrange your work as illustrated on page 25.

LESSON: 8 .

FARM EXPENDITURES.

Next enter the Expenditures for April.

Step 1. Turn to page 3 in your Cash Book and enter. (See page 23).

April 1. On Household Expenses, $\$ 30.00$. (Total and Household columns.)

1. $12 \mathrm{bu}$. Seed Wheat at $831-3 \mathrm{c}$.

3. Labor in Garden, $\$ 1.50$; Shod Cap and Maud, $\$ 3.00$.

5. Interest M. P. Co., $\$ 20.00$; Jersey Cow, $\$ 65.00$; Laths and Shingles, \$3.75.

6. Garden Seed, $\$ 1.60$; Road Tax, $\$ 3.00$.

8. Addition to barn (contract), $\$ 80.00$; Crates and Bags, $\$ 15.40$.

9. Wages to Johnson, $\$ 10.00$; Steel Frame Grindstone, $\$ 3.50$. 
12. 200 ft. Lumber, $\$ 10.00$ per M.; 1 Shovel, $\$ 1.25$.

13. On Household Expenses, $\$ 30.00$; John Smith, labor, $\$ 2.50$; Staples, $35 \mathrm{c}$.

14. Taxes, $\$ 30.40$.

15. Cash for personal use, $\$ 3.50 ; 1$ Rip Saw, $\$ 2.50$; Paid O. N. Smith in full, $\$ 15.80$.

17. Pruning Orchard, $\$ 2.50$; Chicken Feed, $\$ 5.00$.

19. Manure from Kimball Livery, $\$ 15.00$; Horse Shoeing, $\$ 2.50$; Trip to Ames, $\$ 4.50$; Patent Fertilizer, $\$ 6.40$.

20. Leghorn Pullet, $\$ 2.10$; Plastering and Paperhanging, $\$ 15.00$; 2 Halters at 90c; Wages to Johnson, $\$ 10.00$.

23. On Household Expenses, $\$ 30.00$; Trees and Shrubs, I. N. C., $\$ 25.80$; Alfalfa Seed, $\$ 3.20$; 2 doz Leghorn Eggs, $\$ 5.80$.

25. Interest on Binder note, $\$ 2.00$; Angora Goat, $\$ 10.00$; Private Expenses, \$5.00; Half doz. Gopher Traps, \$1.50.

26. Repairs on Horse Stalls, $\$ 13.50 ; 1$ Keystone Dehorner, $\$ 10.50$.

29. 2 Geese, $\$ 3.00$; Wages to Johnson, $\$ 10.00$; Apple Boxes, $\$ 3.75$.

30. Butter Wrappers, $\$ 1.75$; Life Insurance Premium, $\$ 35.10$; Produce for Household, $\$ 18.05$.

Step 2. Add the columns. The correct results are as follows: Total, $\$ 575.20$; Household and Personal, $\$ 113.95$; Seeds and Fertilizers, $\$ 62.00$; Hired Labor, $\$ 36.50$; General Expenses and Marketing, $\$ 30.90$; Stock and Feed, $\$ 90.90$; Marhinery, Implements and Tools, \$21.05; Repairs, \$111.60; Sundries, $\$ 106.30$. Note that the total of the distribution columns equals the total column.

Step 3. By going through the Sundry column we find that it contains the following:

Interest .$\$ 22.00$

Taxes 33.40

Accounts Payable................. 15.80

Insurance 25.10

Total

$\$ 106.30$

Step 4. Classify the Improvements and Repairs column. The correct result is as follows:
improvements
.$\$ 80.00$
Repairs
34.60
Total
$\$ 114.60$

Step 5. Balance the Cash by taking the difference between the Recefpts and Expenditures. The correct difference is $\$ 74.34$. 


\section{LESSON 9 . \\ THE BANK ACCOUNT.}

We have found it profitable and convenient to carry an account with the Citizens' National Bank, and the transactions during the month have been as follows: Deposits, April 1, $\$ 98.75 ;(6), \$ 90.00 ;(9), \$ 40.50 ;(13), \$ 125.00$. The checks drawn, beginning with No. 350, are as follows: April 1, Mrs. Martin Harris, $\$ 30.00$; Odell Seed Co., $\$ 10.00$; (3), Emma Johnson, $\$ 1.50$; Brown \& Pickett, $\$ 3.00$; (5), Salem Implement Co., $\$ 20.00$; E. Skidmore, $\$ 65.00$; Empire Lumber Co., $\$ 3.75$; (6), County Recorder, $\$ 3.00 ;(8)$, Earle \& Crockett, $\$ 80.00$; Farmers' Supply Co., $\$ 15.40$; (9), Frank Johnson, $\$ 10.00$; Goddard Hardware Co., \$3.50; Mrs. Martin Harris, $\$ 30.00$; Crown Fertilizer Co., $\$ 6.40 ;$ O. N. Smith, $\$ 15.80$; (13), County Treasurer, $\$ 30.40$; Kimball Livery Co., $\$ 15.00$; Brown \& Pickett, $\$ 2.50$; $(20)$,C. J. Olson \& Son, $\$ 15.00$; Horning \& Bacon, $\$ 10.00$; Crawford Hardware Co., $\$ 10.50$.

\section{Directions.}

Step 1. Enter the above on a sheet of Journal paper, as illustrated on page 27 . Extend the balances after numbers $351,354,358,368$ and 370 .

Step 2. At the end of the month add the checks and deposits and find the difference. The resulting balance should be $\$ 29.80$.

Step 3. The bank has returned your Pass Book with the canceled checks. You have arranged them numerically and find that all are returned except Nos. 361, 366 and 369. In other words, the bank has paid all except these checks. By adding the outstanding checks to your balance you find that the bank balance ought to be $\$ 58.30$, which you find agrees with the Pass Book. The canceled checks should be filed numerically and kept for future reference. An endorsed check is a valid receipt.

\section{LESSON 10.}

\section{FINANCIAL STATEMENT No. 3.}

Under ordinary circumstances a financial statement should be made out only once a year, but for additional practice you may prepare a Balance Sheet at the end of the first month. As will be observed on page 35 , the Balance Sheet is a condensed statement of the last year's inventory and the new; the total Cash Receipts and Expenditures as they appear in the different columns of the Cash Book, and, finallv, a detailed statement of Profits and Losses. Your Balance Sheet will be exactly like that on page 36 , when completed. The new inventories are as follows: Farm, $\$ 8,700.00$; Cash and Bank, 
$\$ 74.34$; Stock and Feed, $\$ 2,145.00$; Grain $\$ 105.00$; Hay, $\$ 55.00$; Orchard and Garden, \$35.20; Dairy Products, \$26.30; Poultry, $\$ 122.80$; Machinery, Implements and Tools, $\$ 870.05$; Household Accounts, \$650.00; Life Insurance, \$1,136.80; General Supplies, $\$ 25.00$; Hired Labor, $\$ 85.00$; Bills Payable, $\$ 3,200.00$; Accounts Payable, \$326.52.

Divections.

Step 1. Turn to the first Balance Sheet ( cover of the Cash Book). Enter in column 1 the Inventories (Resources and Liabilities found in statement No. 2). In column 2 enter the new inventories given above.

Step 2. Add the Kesources and Liabilities of both columns; check with the totals in the illustration. Then find the Net Worth and the Profit or Loss. In this case there is a loss of $\$ 1.01$, due to the fact that April is naturaliy an unproductive month for the farmer.

Step 3. Enter the total Receipts and Expenditures from the Cash Book into columns 3 and 4 respectively as shown on page :36. The Cash Balance is entered in column 2 opposite Cash. Add and see to it that the columns balance.

Step 4. You will now find the Profits and Losses. The first item shows neither profit nor loss, since the payment equals the difference between the inventories. In Stock and Feed there is an increase in inventory of $\$ 179.00$ and the receipts exceed the expenditures by $\$ 71.10$; hence a profit of $\$ 250.10$. By a careful study of the illustration you will have no difficulty in finishing the Balance Sheet. The total profits are $\$ 433.05$; the losses, $\$ 434.06$; hence we find the same loss as before, $\$ 1.01$, which proves the correctness of our work.

Step 5. Total all the columns as illustrated in the "Totals to Balance" space.

By a carefui study of the Balance Sheet you will find very important differences between this statement and numbers 1 and 2. Here you show not only the net loss, but also the sources of the profits and losses, as well as a statement of the Cash Receipts and Expenditures. Moreover, by finding the net profit or loss in two different ways, one proves the correctness of the other. 
CHAPTER XI.

\section{PRACTICE WORK IN DOUBLE ENTRY -SET 2.}

For the purpose of additional practice you may now write up the last month of the year, carrying forward assumed totals so as to enable you to prepare a complete Balance Sheet at the end of the year. It will be unnecessary to give further detailed instructions since the steps are exactly the same as in the preceding set.

\section{LESSON 11.}

\section{HOUSEHOLD ACCOUNTS.}

Enter as usual the following Household Receipts and Expenditures:

March 1. Oranges, 25c; James, 35c; Codfish, 35c; Allow. ance, $\$ 30.00$; Coffee, $\$ 1.00$; Bacon, 50c ; Shoe Laces, $10 c$; Fish, 25c; Veal, 10c; Whale Bone, 10c; Stove Polısh, 25c.

3. Jardinier, 25c ; Collars, 25c; Tacks, 10c; Collection, 25c ; Buttons, 10c; Tooth Brush, 25c; Talcum Powder, 25c; Stamps, 25c; Oranges, 25c; Thread, 15c; Meat, 50c; Crackers, 25c.

7. Help, $\$ 1.00$; Roast, 55c; Delineator, 10c; Pepper, $15 \mathrm{c}$; Comb, 25c; Oatmeal, 25c; Meat, 40c.

9. Collection, $25 \mathrm{c}$.

10. Gloves for Ella, 75c; Postage, 25c; Starch, 10c.

12. Chops, 25c; Beans, 25c; Mustard, 20c; Soap, 30c; Borax, 15c; Pattern, 45c; Muslin, 50c; Music, 20c; Gasoline, $\$ 1.20$; Picture Frames, $\$ 3.45$.

14. Starch, 25c; Help, $\$ 1.00$; Laundry, $\$ 1.00$; Allowance, $\$ 30.00$.

15. Coffee, 35c; Music, 25c; Collection of Poems, $\$ 1.50$.

16. Collection, 25c; (17) Telephone Rental, $\$ 1.50$.

17. Steak, 30c; Rocker, \$3.75; Suit for George, $\$ 15.00$; Skirt Cleaned, 75c; Cheese, 50c; Tongue, 25c; Thread, 10c; Tooth Picks, 10c; Sugar, $\$ 1.00$; Medicine, 50c.

19. Lemons, 20c; Lace, 15c; Telegram, 60c ; Scissors Sharpened, 10c ; Flour, $\$ 1.20$; Graham, 25c ; Rock Candy, 10c ; Coal, $\$ 5.00$; Powdered Sugar, 25c; Granulated Sugar, $\$ 1.00$; Piano Tuned, $\$ 5.00$; Oranges, $25 \mathrm{c}$; Birthday present to Mother, $\$ 5.00$.

21. Laundry, 55c; Help, 75c; Pens and Pencils, 10c; Hat, $\$ 4.00$; Hooks and Eyes, $10 \mathrm{c}$; Collar, 35c ; Sugar, $\$ 1.00$; Crackers, 10c; Cheese, 25c; Mustard, 10c; (23) Collection, 25c.

24. Braid, 45c; Fish, 15c; Coffee, 45c; Picture of Baby, $\$ 1.50$; Asbestos Pad, 15c; Roast, 45c; Oranges, 20c; Allowance, $\$ 30.00$. 
26. Help, \$2.00; Tailoring, \$1.45; Pepper, 10c; Needles, $10 \mathrm{c}$; Trip to Boone, \$2.00; Hats for George and James, \$3.50.

28. Ella, $\$ 1.00$; Shoes Repaired, \$1.25; Flower Seed, 25 ; Braid, 15c; Thread, 10c.

29. Help for Month, $\$ 10.00$; Laundry, $\$ 1.00$.

30. Collection, 35c.

31. Butter, Milk and Cream for Month, $\$ 6.45$; Poultry for Month, \$4.65; Vegetables for Month, $\$ 2.80$.

Add all the columns. The results should be:

Cash, $\$ 111.60$; Garden, $\$ 2.80$; Dairy, $\$ 6.45$; Sundries, \$4.65; Expenditures: Groceries. $\$ 12.75$; Meat, $\$ 3.70$; Poultry and Dairy, $\$ 11.85$; Clothing, $\$ 29.00$; Furniture and Utensils, $\$ 7.60$; Help and Laundry, \$17.30; Books and Education, \$2.05; Physician and Medicine, 50c; Light and Fuel, \$6.20; Gifts, \$6.35; ; Personal, $\$ 1.35$; Incidental, $\$ 13.95$. Balance as before $(\$ 12.90)$.

\section{LESSON 12 .}

FARM RECEIPTS.

Enter as usual.

March 1. Forwarded: Receipts, $\$ 3,644.34$; Grain, $\$ 591.93$; Hay, $\$ 134.95$; Orchard and Garden, $\$ 277.95$;Stock, $\$ 1,110.50$; Dairy, $\$ 997.07$; Poultry, $\$ 246.14$; Sundries, $\$ 285.80$.

March 1. 2 Pigs at $\$ 6.25$; (3) 20 bu. Apples, 65c; 50 bu. Potatoes, 45c.

7. 3 Tons Clover at $\$ 6.50 ; 1$ Veal Calf, $\$ 9.00 ; 40$ bu. Oats, $45 \mathrm{c}$.

9. 25 lbs: Dressed Chicken at 20c.

10. 10 doz. Eggs, $15 \mathrm{c} ; 1 \mathrm{Cow}, \$ 45.00$.

12. 1 Ton Clover, $\$ 6.50$; Sold Old Wagon, $\$ 10.00$.

15. Hired out Team and Buggy, $\$ 4.00$; Labor on County Road, $\$ 5.00$.

16. 50 bu. Corn at $60 \mathrm{c} ; 95$ Boxes Strawberries at $15 \mathrm{c} ; 10$ lbs. Butter at 25c.

19. 3 Tons Timothy at $\$ 5.75$; 3 Days Labor for Johnson and Co. at $\$ 1.60 ; 14$ doz. Eggs at $15 \mathrm{c}$.

21. 2-year-old Colt, $\$ 75.00$; Strawberry Plants, $\$ 4.60 ; .18$ 11)s. Butter at 25c; 4 qts. Cream, $15 \mathrm{c} ; 4$ Calves at $\$ 12.00$.

¿4. 50 bu. Oats at $40 \mathrm{c} ; 10$ Dressed Chickens at 30c.

28. 50 bu. Corn at $65 \mathrm{c}$; 3 Tons Timothy at $\$ 5.00$; Sold one Set Harness, $\$ 32.40 ; 2$ Tons Clover at $\$ 5.50$.

30. 50 bu. Barley at 40c.

31. Produce used for Household, $\$ 13.90$.

31. From Phoenix Hotel, $\$ 7.00$ for Cream.

Add all the columns and prove. The correct total is $\$ 1,17.24$. The Sundry column is segregated as follows: Sale of Implements, etc., $\$ 60.81$; Labor Earnings, $\$ 155.15$; Cash Balance, $\$ 126.04$. 
LESSON 13.

Enter as usual.

FARM EXPENDITURES.

March 1. Amounts forwarded: Total payments, $\$ 3,513.63$; Household ana Personal, $\$ 1,028.90$; Trees, $\$ 99.66$; Hired Labor, $\$ 386.00$; General Expense and Marketing, $\$ 269.49$; Feed and Stock, \$427.85; Machinery and Tools, \$172.31; Improvements and Repairs, $\$ 513.20$; Sundries, $\$ 616.22$.

March 1. On Household Expense, $\$ 30.00$.

3. 200 feet Lumber, $\$ 10.00$ per M. ;20 Posts, $\$ 1.60 ; 1$ Shovel ,\$1.25.

7. Strawberry Crates, $\$ 4.00$; Assessment Farmers' Telephone Co., $\$ 2.00$; Shod Prince, $\$ 1.50 ; 11 / 2$ bu. Timothy Seed at $\$ 1.10$.

9. 10 bu. Rye Seed at $60 \mathrm{c} ; 1$ Cultivator, $\$ 25.00$.

10. Setting Tire on Wagon, $\$ 3.00$; Half Month's Wages to Frank, \$15.00.

12. Advertising Garden Products, $\$ 1.20$; Membership in Breeders' Association, $\$ 3.00$; Incubator, $\$ 20.00$.

14. On Household Expenses, $\$ 30.00$; Insu-ance, 3 Years, $\$ 29.50$.

15. 1 Set Plymouth Eggs, 50c.

16. 2 Sets Leghorn Eggs, 50c; Dehorning Cattle, \$3.25; 100 lbs. Wire at 3c.

17. Labor on Ditch No. 1, $\$ 16.50$; Labels for Apple Boxes, $\$ 4.20$; Garden Seeds, $\$ 3.40$.

19. Carpentry Tools, $\$ 2.50$; Harness Oil, $\$ 1.00$; Bran and Shorts, $\$ 5.60$; Subscription to Y. M. C. A., $\$ 5.00$.

21. $10 \mathrm{lbs}$. Nails at $6 \mathrm{c}$; Blacksmithing as per Bill, $\$ 3.00 ; 40$ Apple Trees at 20c; 10 Peach Trees at 25c; Paid Frank on Wages, $\$ 5.00 ; 5$ Sacks Phosphate, $\$ 8.50$.

24. On Household Expenses, $\$ 30.00$; Labor in Orchard, $\$ 2.00$.

26. Shovel and Hoe, $\$ 1.50$; Allowance for James at College, $\$ 20.00$.

28. 1 Plow Share, $\$ 3.20$.

29. Balance Wages to Frank, $\$ 10.00 ; 1$ bbl. Salt, $\$ 2.50$; 2 Pigs, $\$ 4.50$; Church Subscription, $\$ 5.00$; Shingles and Nails, $\$ 1.00$.

30. Taxes, $\$ 38.60$; Paid George for Keeping Books, \$5.00.

31. Produce for Household, \$13.90; Labor in Garden, \$1.20.

Add all the columns and prove. The correct total is $\$ 3,-$ 902.28 .

If you could go through the entire Sundry Column for the year, you would find the following iterns: Life Insuranee, $\$ 54.30$; Accounts Payable, $\$ 252.32$; Insurance, $\$ 29.50$; Interest, $\$ 230.00$; Taxes, $\$ 38.60$; Charities, etc., $\$ 94.60$. The Im- 
provement and Repair column is segregaterl as follows: Improvements, $\$ 350.00$; Repairs, $\$ 174.40$. The Household and Personal column shows: Household, \$1,074.40; Personal, $\$ 83.40$.

Arrange all the above as illustrated on page 23.

\section{LESSON 14.}

FINANCIAL STATEMENT No. 4.

We have now arrived at the end of the second year and we are ready to prepare the annual Balance Sheet. This is exactly like number three in form and there is no difference in the method of preparing it. The new inventories are as follows: Farm, $\$ 9,070.00$; Cash and Bank, $\$ 271.96$; Stock and Feed, $\$ 1,948.50$; Grain, $\$ 380$; Hay, $\$ 168.75$; Orchard and Garden, $\$ 45.00$; Poultry, $\$ 100.55$; Machinci'y and Implements, $\$ 953.00$; Household Account, $\$ 682.40$; General Expense and Marketing, \$37.80; Life Insurance, $\$ 1,136.80$; Total Resources, $\$ 14,794.76$. Liabilities: Hired Labor, $\$ 35.00$; Bills Payable, $\$ 3,200.00$; Accounts Payable, $\$ 90.00$; Gifts, $\$ 40.00$; Total Liabilities, $\$ 3,365.00$. The net worth is $\$ 11,429.76$; the net profit is $\$ 1,094.78$.

Hand in all your work, properly copied in ink, for approval. 
CHAP'TER XII.

\title{
ORIGINAL EXERCISES AND REVIEW.
}

\author{
LESSON 15.
}

\section{ORIGINAL FARM ACCOUNTS.}

In order to gain additional practice and confidence in your work, you may now prepare an original set similar to the ones already worked out. Study over the work already completed, and if you have any suggestions and criticisms of the system of accounts, talk them over with your instructor. If your suggestions are acceptable, you may embody the changes in this set, otherwise you will follow the preceding sets very closely. The complete set must have at least five entries in each column, and the totals should not be far from those in the sets already completed. A higher grade of work is expected than heretofore.

Directions.

1. Prepare an inventory similar to the one shown on page 15. The amounts should be close to the results given in lesson 14 .

2. Write two months' imaginary entries as close to actual experience as possible. Students from the farm should secure the material from home or from farmer friends.

3. Complete the year's work by taking estimates for the remaining months.

4. Prepare a closing inventory for the end of the year.

5. Prepare a Balance Sheet similar to the one given on page 36.

6. Hand in your work with suggesticns and criticisms.

LESSON 16

\section{ORIGINAL HOUSEHOLD ACCOUNTS.}

Prepare an Original Household Record on the same plan as the Original Farm Record. The totals should conform approximately with one of the months in the Household Summary.

Hand in your work for approval .

LESSON 17.

ORIGINAL BALANCE SHEET.

Prepare a Balance Sheet of the work done in the two preceding lessons, exactly like the one you prepared last, and hand in for approval. 
LESSON 18.

ORIGINAL SHOP ACCOUNTS.

- Farm and Shop bookkeeping do not differ in principle. They differ only in titles of accounts. The books used are the same as in the farm accounts, except special records adapted for the needs of the shop. The Labor Record need not differ at ail. Taking the Cash Book furnished in your set, note that the number of columns and the arrangement is exactly the same as in the farm accounts. Only the titles of the columns are different. The titles given below are self-explanatory, except the Merchandise and the Supply Column. A large number of shops and milis carry a small stock of merchandise which is suld at retail. Where this is done, it is preferable to keep it sirictly separate from the manufacturing end of the business. The shop should buy from the store at regular prices, and charge it with any supplies furnished for sale. Where it is found impracticable to keep a separate set of books, a column is provided for receipts from merchandise solid and one for payments for merchandise purchased. Taking into account the inventories at the beginning and end of the year, these columns give the result of this branch of the business. In the Supplies Column is entered only consumable material used in the process of manufacture, such as oil, cotton waste, sandpaper, files, and the like. The Sundries Column is used for all items which do not fall under any special column. For instance, if interest is paid on a note, it is entered in the total payments column and also in the Sundries Column, and under "Charge to" would be entered "Interest." It is frequently necessary to show hospitality in closing deals in which a shop of any consequence is interested. Such entertainment expenses would be entered in the Incidental Column.

\section{Hin.litns:}

1. Head all the columns in the Cash Book as follows: Inder Receipts: Merchandise, Manufacturing. Under Payments: Hardware, Lumber, Supplies, (Machinery and 'Tools), Repairs, (Buildings and Improvements), Labor, (Freight and Express), Office, (Light, Fuel and Power), Merchandise.

2. Prepare an imaginary inventory of a planing mill, with $\$ 10,000.00$ capital, having a merchandise inventory of $\$ 2,000.00$ consisting of house-fittings, light hardware, etc. Use the form illustrated on page 17.

3. Write up an imaginary month's business of receipts and payments, taking care that there be at least two entries illustrating each column. Follow the plan illustrated on page 22 .

1. From the above figures, prepare a probable estimate of the years business.

5. Prepare a Balance Sheet similar to the one shown on page 36. 6. Hand in your work for approval. 


\section{LESSON 19.}

ORIGINAL HORTICULTURAL SET.

The remarks in Lesson 18 regarding the relation between Farm and Shop accounts hold true also for Farm and Horticultural accounts.

\section{Directions.}

1. The Farm Cash Book may be used with the same titles, except under Grain, write Apples, under Hav, write Peaches. We will assume that enough animals are kept on the farm to warrant keeping accounts of the stock, dairy and poultry. The payments columns can be exactly the same.

2. Prepare an imaginary inventory of about $\$ 5,000.00$ net capital.

3. Prepare an imaginary month's business, same as in the preceding lesson.

4. Prepare an estimate of the year's business.

5. Prepare a Balance Sheet.

6. Hand in work for approval with suggestions and critic. isms.

\section{LESSON 20 .}

\section{PERSONAL ACCOUNTS.}

The student will find it a valuable exercise to keep account of his personal expenditures in the Cash Book provided in the supplies. The columns may be headed as follows: Receipts: Earnings, From Home. Payments: Fees, (Books and Stationery), Board, Room, Clothing, Recreation. This will not be required of all students, but a semester's record of the student's actual expenses will be accepted instead of any original set. Whether submitted for credit or not, all students are urged to keep an accurate record of their personal expenses.

\section{LESSON 21.}

PREPARATION OF SPECIA, RECORDS.

\section{Directions.}

1. Procure about two dozen sheets of good quality, unruled paper (or use blank filler in the note book), a ail eut it $81-2 \times 11$ inches.

2. Lay out in lead pencil the special records illustrated on nages 46 to 49 , putting only one record on a page. Sharpen your pencil to a fine point. The width of the column should be planned on a strip of paper before the work is begun. Rule lightly, so as to be able to make corrections readily.

3. Submit the work to your teacher for approval before inking. 
4. Ink the approved work and fill in the proper headings. The horizontal lines are not to be inked except the heading lines.

5. Hand in work for final approval.

LESSON 22.

\section{COST RECORDS OF S'TOCK.}

According to either the second or third method outlined on page 41 , prevare a statement of the net profit or loss of not less than five milch cows. Your information may be drawn from any farm, from the College Department of Dairying, or from Agricultural Bulletins. The records required are: Labor, NIilk, Feed Record, and the Individual Ledger account of each animal. Two months will be allowed for this work. Rulc your records as explained in Lesson 21.

Hand in your work with a letter of explanation of the system.

LESSON 23.

COST RECORDS OF CROPS.

In a similar manner, prepare Cost Record, showing the net profit or loss of two crops, from information secured from reliable sources. Any local crop may be taken, such as potatoes, wheat, oats, hay, etc. Two months will be allowed for the work. tem.

Hand in your work with a letter of explanation of the sys-

\section{LESSON 24.}

THE INVESTMENT.

The Census for 1900 gives the following apportionment for land and improvements, buildings, implenents, machinery, and live stock for every $\$ 10,000.00$ invested:

\begin{tabular}{|c|c|c|c|c|c|}
\hline $\begin{array}{l}\text { Division- } \\
\text { N. Atlantic }\end{array}$ & Total. & $\begin{array}{l}\text { Land } \\
\text { and Impr. }\end{array}$ & Buildings. & $\begin{array}{l}\text { Imp. } \\
\text { and Mach. }\end{array}$ & Live St. \\
\hline $\begin{array}{l}\text { States } \\
\text { S. Atlantic }\end{array}$ & $\$ 10,000$ & $\$ 5,737$ & $\$ 2,567$ & $\$ 606$ & $\$ 1,090$ \\
\hline $\begin{array}{l}\text { States .... } \\
\text { N. Central }\end{array}$ & 10,000 & 6,661 & 2,720 & 332 & 1,362 \\
\hline $\begin{array}{l}\text { States .... } \\
\text { S. Central }\end{array}$ & 10,000 & 6,055 & 825 & 500 & 2,620 \\
\hline $\begin{array}{l}\text { States .... } \\
\text { Western }\end{array}$ & 10,000 & 4,114 & 1,114 & 373 & 4,356 \\
\hline States .... & 10,000 & 4,463 & 693 & 593 & 4,251 \\
\hline Total & $\$ 50,000$ & $\$ 27,030$ & $\$ 7,919$ & $\$ 2,40.4$ & $\$ 13,679$ \\
\hline Average & $\$ 10,000$ & $\$ 5,406$ & $\$ 1,584$ & $\$ 481$ & $\$ 2,73$ \\
\hline
\end{tabular}


Secure at least five inventories from your farmer friends and prepare a statement similar to the above table. Prepare a condensed report to be presented to the class when called for, giving the source of your information, if required.

Hand in your work for approval.

\section{LESSON 25.}

THE FARM PLOT.

Draw to scale any farm with which you are acquainted. Lay out the various fields and mark the crop and acreage as shown on page 49. 1)raw it first in lead pencil, then in ink.

Hand in the work for approval.

\section{LESSON 26.}

\section{AGRICULTURAL STATISTICS.}

It is desired to obtain accurate data on Farm Management, and you are required to write to ten farmer friends for certain information. Copies of a letter will be furnished by your teacher. (A copy of the proposed letter will be furnished any teacher by the author.) Tabulate the result and prepare a report to be discussed by the class.

\section{LESSON 27.}

REVIEW QUESTIONS.

Write the following questions and their answers on paper $81-2 \times 11$ inches and submit to your teacher for approval:

1. What is the object of keeping books?

2. What is the use of the Day Book? Prepare a specimen day book page of at least five entries.

3. What entries are properly made in the day book?

4. Describe the Bill and Receipt File and explain its use.

5. How is an inventory taken? Of what does it consist?

6. What are Resources? Liabilities? Profits? Losses?

7. What are Accounts Receivable? Accounts Payable?

8. Prepare a specimen Account Receivable and also a specimen Account Payable.

9. What should determine the time of the year when the farm Balance Sheet is taken?

10. What are the disadvantages of Single Entry?

11. Prepare a specimen of each of the Special Records suggested on pages 46 to 49 .

12. Which is the principal book in the second method? (Double Entry.)

13. What is the value of the special column provided in the Journal? Suggest columns that might be added.

14. How is each side of the Cash Book balanced?

15. How do you find the cash on hand?

16. If a bank account is kept, how do you find the cash on hand? 
17. Describe how household accounts are kept.

18. What allowance for household besides cash? Why are these allowances both debited and credited at the time they are entered? How are these allowances entered in the General Cash Book?

19. How is the cash on hand found in the household account?

20. Describe how the Sundry Columns are itemized.

21. Of what three principal headings does the Financial Statement consist?

22. State the steps necessary in preparing the Financial Statement.

23. State some of the advantages of banking.

24. What is meant by depreciation? What are the rates commonly used?

25. How may land be said to depreciate in value?

26. Describe three methods of finding the profit, or loss, from live stock. From different crops.

27. What is the principal difference between farm and shop accounts?

28. How may a large crop prove to be a loss to the community?

29. Write a paragraph, pointing out the importance of records for the farmer.

30. Write a paragraph of general review of the system of bookkeeping you have now finished, and point out its merits and defects.

31. In finding the actual net gain or loss on accounts of production, what corrections must be made?

:32. Give the rule for finding the profit or loss in the Balance Sheet.

33. What is the distinction between equipment and supplies?

34. What is the distinction between improvements and repairs?

HIBIIOGRAPHY.

Farm Management......................... Cord The Modern Farmer. ...................... F. Adams The Farmer's Business Handbook. ......... Isaac P. Roberts Agricultural Economics................... Henry C. Taylor The Business of Dairying.................. . B. Lane Farm Accounts.......................... A. Vye Bulletin No. 97. University of Minnesota Bulletin No. 48 ... Bureau of Statistics, Dept. of Agriculture 


\section{INDEX}

Accounts,

Value of.

Farm

Horticultural

Household.

Personal.

Shop.

Agriculture, statistics of.

Balance Sheet, 35; illustrated....... 36
Bank Account, explained........... 26

Bibliography

Bill and Receipt File,

Explained, II; illustrated........ I3

Blank Books

Bookkeeping,

Difficulties of Farm

Objects and Methods of

Cash Book,

Explained.

Illustrated

Cost of Production

Of Crops

Of Live Stock

Dairy Herd, Test of.

Day Book, explained II, illustrat. I2

Depreciation........................... I 4

Double Entry....................... 2 2 I

Books Needed....................... 24

Compared with single ............ 24

Superiority of .................... 2 I

Equipment . ...................... 25

Exchange Phase, importance of ... 8

Farming, a paying business........ 8

History of the Farm................. II

Household Accounts............... 30, 32

Improvements...................... 25
Introductory ........................ 7

Inventory,

Explained.......................... I4

Illustrated .......................... I5

Continued ......................... 20

Investment............................ 68

Labor, Records ........................ 46

Ledger ................................ 26

Live Stock, cost of production..... 4I

Methods of Bookkeeping............ 9

Milk Records........................ 44

Office Methods ...................... 45

Personal Accounts................. 18, I9

Phases of Farming................... 8

Plot, the Farm .................... 49

Poultry Records...................... 44

Practice Work,

Double Entry ..................... 55

Origina1............................. 65

Single Entry....................... 50

Profits, How to Determine.......... I4

Profit and Loss Statement... ........ I7

Prosperity of the Farmer......... 7

Questions, Review.. ............... 69

Rates of Depreciation............... I4

Records, what they should show... 9

Sales Book, duplicating............ 44

Shop Accounts ........................ 66

Single Entry......................... II

Special Records...................... 44

Statement for Publication.......... 37

Success, Causes of.................... 7

Supplies............................. 25

Trial Balance,

Explained......................... 26

Illustrated...................... 31 
10t 951508 



